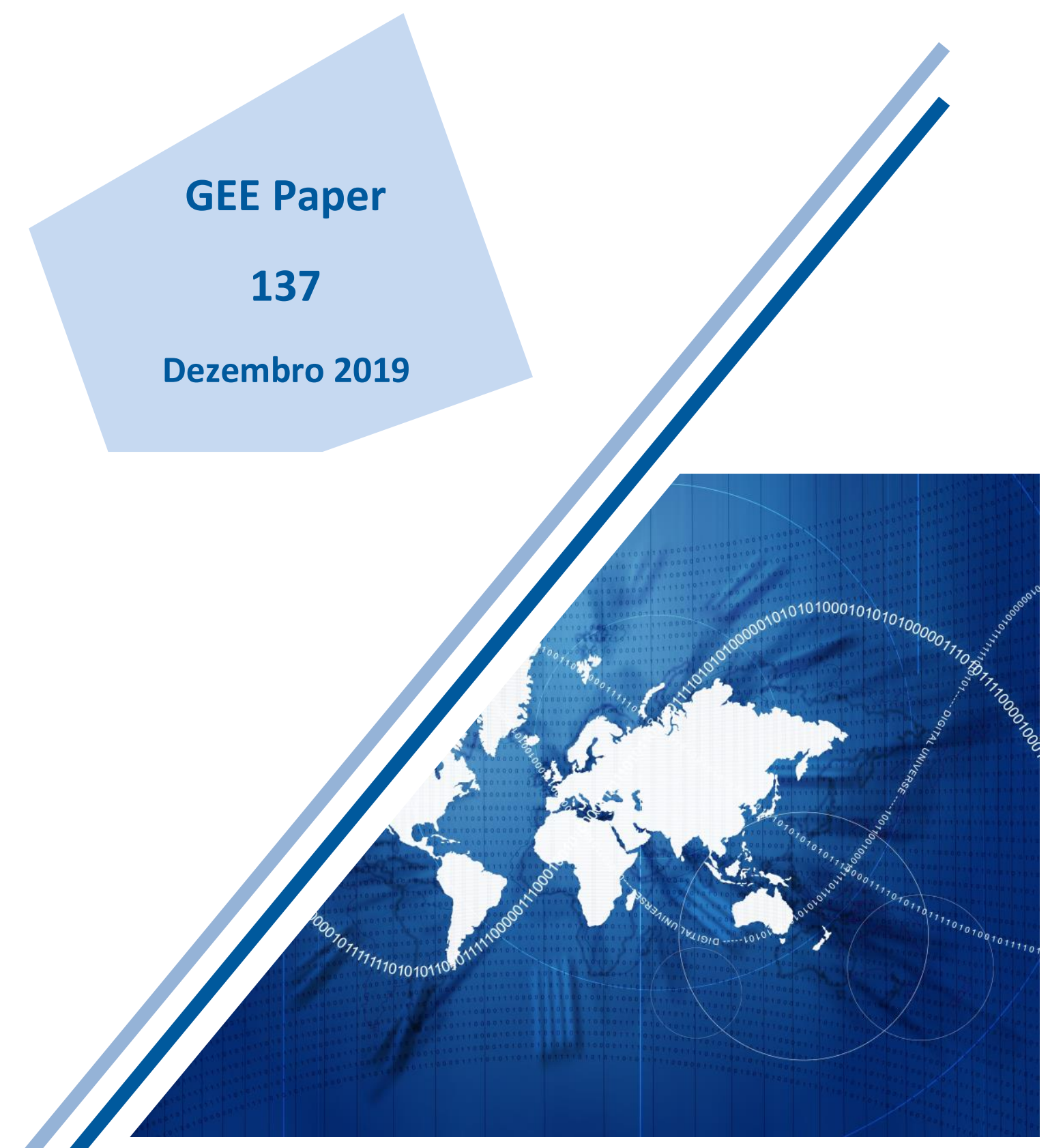

Collateral Value and Entrepreneurship: Evidence from a Property Tax Reform

Miguel Ferreira | João Pereira dos Santos | Ana Venâncio 
Gabinete de Estratégia e Estudos 


\title{
Collateral Value and Entrepreneurship: Evidence from a Property Tax Reform ${ }^{1}$
}

\author{
Miguel Ferreira 2 João Pereira dos Santos? Ana Venâncio 4
}

\begin{abstract}
:
We study the role of property taxes on entrepreneurial activity using a quasi-natural experiment, which unexpectedly reduced the upper bound of the Portuguese property tax rate for urban properties in 2008. Using a difference-indifferences approach, we find that treated municipalities (i.e., municipalities that had a property tax rate above the new upper bound) experienced higher entry rates in the manufacturing sector vis-à-vis control municipalities (i.e., municipalities that had a property tax rate at or below the new upper bound). Taking advantage of firm-level data, we show that start-ups created as a response to the decrease in property taxes in treated municipalities use more debt, invest more, and are more likely to survive.
\end{abstract}

JEL Classification Codes: L26, H20, H30

Keywords: Entrepreneurship, Property taxes, Savings, Portugal Note: This article is the sole responsibility of the authors and does not necessarily reflect the
positions of GEE or the Portuguese Ministry of Economy.

\footnotetext{
${ }^{1}$ This work received financial support from Fundação para a Ciência e Tecnologia (PTDC/EGE-ECO/31213/2017). The authors are grateful to the Portuguese Ministry of Employment and Social Security and Gabinete de Estratégia e Planeamento (GEP) for access to the matched employer-employee data and Statistics Portugal for access to the financial database. We thank Álvaro Silva from Statistics Portugal for his research assistance. We received helpful comments from Juanita Gonzalez-Uribe, Bill Kerr, Gustavo Manso, Tuomas Matikka, Ramana Nanda, Gabor Pinter, Melissa Prado, Susana Peralta, Francisco Queiró, David Thesmar, Antoinette Schoar, Carles Vergara-Alert and seminar participants at Nova SBE, the $45^{\text {th }}$ Eastern Economic Association (NY), the AREUEA (Bocconi), the $4^{\text {th }}$ Workshop on Spatial Dimensions of the Labour Market (Aix-Marseille), IIPF (Glasgow), and EEA (Manchester). João Pereira dos Santos gratefully acknowledges financial support by FCT - Fundação para a Ciência e Tecnologia - PD/BD/128121/2016. Views expressed are those of the authors and do not necessarily reflect those of any branch or agency of the Government of Portugal. All errors or omissions remain our own.

${ }^{2}$ Nova School of Business and Economics miguel.ferreira@novasbe.pt)

${ }^{3}$ Nova School of Business and Economics joao.santos@novasbe.pt.)

${ }^{4}$ ISEG and ADVANCE/CSG avenancio@iseg.ulisboa.pt
} 


\section{Contents}

1 Introduction 1

2 Institutional Background 3

3 Data and Variables 3

4 Empirical Strategy 5

4.1 Municipal-level Analyses . . . . . . . . . . . . . . . . . . . . . . . . . . . . . . . . . . . . 5

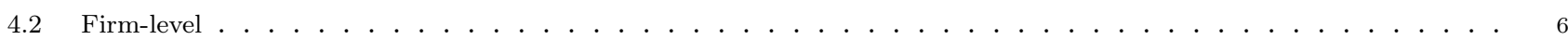

5 Main Results 6

$5.1 \quad$ Municipal-level Baseline Results $\ldots \ldots \ldots$

5.2 Internal Validity . . . . . . . . . . . . . . . . . . . . . . . . . . . . . . . . 7

5.3 Robustness Results . . . . . . . . . . . . . . . . . . . . . . . . . . . . . . . 7

5.4 Heterogeneity Results . . . . . . . . . . . . . . . . . . . . . . . . . . . . . 8

5.5 Alternative Mechanisms and Firm-level Results . . . . . . . . . . . . . . . . . . . . . . . . . . . . . . . . . 8

6 Concluding remarks

7 References 10

8 Figures 11

9 Tables 14 


\section{List of Figures}

$1 \quad$ Treated and Control Municipalities ． . . . . . . . . . . . . . . . . . . . . . . . . . . . . . . . . . . . 11

2 Evolution of Entry Rates . . . . . . . . . . . . . . . . . . . . . . . . . . . . . . . . . 12

3 Evolution of Entry Rates . . . . . . . . . . . . . . . . . . . . . . . . . . . . . . . . . . . . . . 13

$4 \quad$ Heterogeneity Results - Manufacturing Sectors ． . . . . . . . . . . . . . . . . . . . . . . . . . . . . 13

\section{List of Tables}

$1 \quad$ Property Tax Rates: Minimum and Maximum Values . . . . . . . . . . . . . . . . . . . . . . . . . . . . . . . 14

$2 \quad$ Summary Statistics for the Municipal-Level Analysis _ . . . . . . . . . . . . . . . . . . . . . . . . . . . . . . 14

3 Baseline Results - Firm Entry Rates . . . . . . . . . . . . . . . . . . . . . . . . . . . . . . . . . . . . 15

4 Baseline Results - Job Creation Rates . . . . . . . . . . . . . . . . . . . . . . . . . . . . . . . . . . . . . 16

5 Balance Tests . . . . . . . . . . . . . . . . . . . . . . . . . . . . . . . . . . . . 17

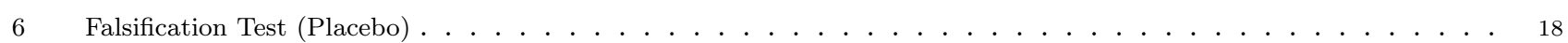

7 Robustness Checks - Intensity of Treatment . . . . . . . . . . . . . . . . . . . . . . . . . . . . . . . . . . 19

8 Robustness Checks - Different Samples . . . . . . . . . . . . . . . . . . . . . . . . . . . . . . . . . . . . 20

9 Robustness Checks - Time and Space . . . . . . . . . . . . . . . . . . . . . . . . . . . . . . . . . . . . . . 21

$10 \quad$ Heterogeneity Results - High vs. Low Technology . . . . . . . . . . . . . . . . . . . . . . . . . . . . . . . . . 22

11 Demand . . . . . . . . . . . . . . . . . . . . . . . . . . . . . . 23

12 Reaction of Municipalities . . . . . . . . . . . . . . . . . . . . . . . . . . . . . . 24

13 Firm Survival . . . . . . . . . . . . . . . . . . . . . . . . . . . . . . . . . . . . . . . 25

$14 \quad$ Financing the Activity: Year 0 . . . . . . . . . . . . . . . . . . . . . . . . . . . . . . . . 26

15 Capital Expenditure and Financing the Activity: Year 5 . . . . . . . . . . . . . . . . . . . . . . . . . . . . . 27 


\section{Introduction}

Encouraging entrepreneurship is a key priority shared by many governments around the world. New ventures are credited not only for increasing competition and pushing out unproductive incumbents, but also for accelerating economic growth and disseminating new technologies. There are several tools to encourage entrepreneurial activity. Most advanced economies provide subsidized loans and loan guarantees based on the premise that there are important credit frictions that preclude individuals with positive net present value projects from entering into entrepreneurship. However, although previous research documents a positive correlation between personal wealth and the propensity to become an entrepreneur (Evans and Jovanovic, 1989, Holtz-Eakin et al., 1994), this might occur due to unobserved differences in productivity, or preferences for entrepreneurship, that are correlated with wealth rather than due to liquidity constraints (Hurst and Lusardi, 2004, Hurst and Pugsley, 2011).

We build on this literature by analyzing a local tax reform, decided by the Portuguese central government, which unexpectedly reduced the upper bound of the municipality property tax (Imposto Municipal sobre Imóveis, IMI) on July 2, 2008 from $0.5 \%$ to $0.4 \%$ We implement a difference-in-difference approach by comparing entrepreneurial outcomes in regions that were forced to reduce the tax rate with those that did not change their tax rate. Underlying our identification strategy is the idea that when property taxes decrease, real estate prices increase (Alvarez and Santos, 2019), and consequently, potential entrepreneurs experience an increase in the value of the collateral available to start a new venture. This allows them to borrow more and thus face less liquidity constraints.

To investigate how changes on the real estate collateral value relates to firm entry, we use a very detailed mandatory survey covering virtually all the firms and employees in the Portuguese private sector. The database contains information on firm's entry year, location, industry and number of employees. We aggregate this information at the municipality level and analyze the period between 2004 and 2011. According with the literature, the reform should be followed by an increase on firm entry in the municipalities that were forced to reduce the tax rate. More specifically, entry should increase for ventures with higher capital needs or facing higher asymmetry of information. In fact, our results suggest that treated municipalities experienced higher entry rates but only in the manufacturing sector vis-à-vis control municipalities. The effect was economically sizable: firm entry rate in treated municipalities increased by $14 \%$, relative to control municipalities in the most saturated specification. In contrast, we find no statistically significant impact of the property tax reform in the service sector. In fact, the average capital needs of the service sector are lower than in the manufacturing sector. Within the manufacturing sector, we find that the reform induced entry of low-technological new ventures, suggesting that real estate collateral increases matter for medium capital intensive ventures.

Possibly, the reduction on property tax reform increased the average real estate price and the collateral that new ventures could use to raise more debt. To investigate this concern, we take advantage of a detailed firm-level financial database. We select start-ups established between 2004 and 2011 and gather comprehensive information on yearly cash, short and long-term debt up to five years following the creation of the new firms. We find that manufacturing start-ups located in municipalities that were forced to reduce the tax rate raise more short-term debt. These results are robust to controlling for a large set of firm and municipality characteristics.

Besides the liquidity constraints theory, other mechanisms might drive the increase on firm entry following a decrease on property tax rates. A reduction in property taxes increases individual's income and wealth in the region encouraging business creation and possibly increasing the amount of debt raised by both individuals and firms. To

5 Peralta and Pereira dos Santos (2018), and Alvarez and Santos (2019) also use the same reform to measure the impact of the tax revenue cut on mayoral decision of seeking re-election and on real estates values, respectively. More specifically, Alvarez and Pereira dos Santos (2019) find that this reform significantly increases the mean real estate values. 
address this concern, we collect data on economic activity and credit supply at the municipality level. We find that municipalities that were forced to reduce the tax rate neither experience larger increases in economic activity, nor changed their spending profile, nor changed the credit provided to both individuals and firms.

Alternately, the decrease in property taxes might have change individual's risk preferences making it more attractive for risk-averse individuals to try their changes in entrepreneurship. To this end, we compute the likelihood of a start-up surviving one, three or five years. We find, that in treated municipalities, new ventures are more likely to survive in comparison to the control group. We find a positive effect on survival for both firms in the manufacturing and service sector.

Our study contributes to two strands of the literature. First, our paper contributes to the effects of taxes on entrepreneurial activity. Earlier research has mainly considered a subset of the taxes facing small businesses and entrepreneurs, focusing mainly on federal taxes ${ }^{6}$ Nevertheless, Neubig et al. (2006) show that the state and local tax burden are extremely relevant for the US businesses. Business and entrepreneurs pay a significant amount of property taxes along with a growing menu of local taxes, licenses and fees. Also, local and central governments continue to enact pro-entrepreneurship policies without the benefits of hard data on the effects of those policies on regional economic growth, new venture creation and innovation. The extent to which local taxes policies influence entrepreneurial activity requires further exploration in order to efficiently design better entrepreneurial policies. Finally, we contribute to the literature on financial constraints and entrepreneurship. The relation between entrepreneurial wealth and firm creation has received considerable attention in the literature but the precise economic mechanisms underlying the role of wealth in firm creation are not well understood. Wealthier individuals have a higher probability of becoming entrepreneurs (Holtz-Eakin et al., 1994, Burke et al., 2000). Nonetheless, previous studies use proxies for liquidity (i.e., assets, wealth and housing prices) that are potentially endogenous because entrepreneurs can accumulate wealth before starting a new venture $(\mathrm{Xu}, 1998)$. To address this concern, other studies use instruments for unanticipated changes in wealth: inheritance (Holtz-Eakin et al. 1994, Blanchflower and Oswald, 1998, Dunn and Holtz-Eakin, 2000), lottery winnings (Lindh and Ohlsson, 1996), and housing capital gains (Hurst and Lusardi, 2004, Nykvist, 2008; Fairlie and Krashinsky, 2012). However, these instruments have inadequacies. Previous literature interprets the positive correlations between wealth and business formation as evidence of credit market imperfections. Alternative explanations include individual characteristics - tolerance for risk, preference for self-finance (Cressy, 1996) and over-optimism (Meza and Webb, 1999) - and greater access to business opportunities (Hurst and Lusardi, 2004). More recently, Adelino, Schoar, and Severino (2015) and Schmalz, Sraer, and Thesmar (2017) show that financial constraints restrict firm creation and growth using variation in house prices as shocks to the value of real estate collateral. These studies identify the effect of liquidity by comparing full homeowners with partial homeowners and renters as only full owners can fund their venture using their houses as collateral to borrow. These two groups, however, may differ in characteristics such as ability and risk aversion, which are important determinants of entrepreneurship.

We extend previous studies in the following ways: (1) we evaluate the effect of a specific local tax, property tax which simultaneously affects businesses- especially small businesses - and entrepreneurs, (2) we take advantage of quasi-natural experience, which significantly reduced local taxes on some specific municipalities, and (3) we analyze how this tax reform affected the capital investments and funding decisions of the new firms.

\footnotetext{
${ }^{6}$ There are four main types of taxes: personal income and payroll taxes, corporate income taxes, capital gain and capital income taxes and wealth and inheritance taxes. Corporate tax refers to the tax that corporations pay on their taxable income. Capital gains tax is paid on profits that an investor receives when he or she sells a capital asset for a higher price than the purchase price. Personal income tax is paid on earned income by the self-employed or wage workers. Capital income tax is paid on dividend or interest income (Block. 2016). Property taxes is paid over the buildings and lands owned by firms and individuals.
} 
The rest of the paper is structured as follows. The next section describes the Portuguese institutional setting. Our data sources, variables, and empirical methodology is presented next. Subsequently, we present our main results, together with a number of robustness checks. In the final section, we present the main conclusions, implications, and limitations of the study.

\section{Institutional Background}

In December 2003, as a result of a general reform of the Portuguese tax system, a new local tax was created: Imposto Municipal sobre Imóveis (IMI) which replaced the previous property tax, Contribuição Autárquica, implemented in 1989. This new tax was automatically applied to new urban constructions and dwellings (reassessed properties). While the fiscal value of the reassessed properties was computed centrally, the tax rate was defined yearly by each municipality within a range previously approved by the Parliament, as displayed in tab:propertytax. Note that the law also applied to the remaining non-reassessed properties and it included a ten year transition period, during which every urban real estate had to be evaluated using the new rules. During our period of analysis, municipalities had to set two different tax rates, for the reassessed and non-reassessed properties. In this paper, we focus on the property tax on reassessed properties since we are measuring the wealth effects that drive individuals to become entrepreneurs and the capital investments done by start-ups.

tab:propertytax displays the lower and upper limits for the reassessed urban properties (IMI). On July 2, 2008, the Portuguese Prime-Minister unexpectedly announced a decrease in the maximum local property tax rate, from $0.5 \%$ to $0.4 \%$ for the reassessed properties. We use this reform as a quasi-natural experiment to define a treated group (i.e., municipalities who were forced, from one year to the next, to decrease the tax rate) and a comparison group (i.e., the municipalities that did not change the tax rate and charge a tax rate between $0.3 \%$ and $0.4 \%$ ) ${ }^{7}$

The map of Portugal with the treated and control municipalities is portrayed in fig:full. By the end of 2008, 94 municipalities were obliged to reduce their tax rate and 162 municipalities maintained their local tax rates. The treated and control municipalities are fairly dispersed through Portugal.

The reform provides good laboratory to study the effects of local property taxes on entrepreneurship because it is based on a single country where the local governments operate under the same institutional background 8

\section{Data and Variables}

To implement our empirical analysis, we use both municipal and firm-level data. More specifically, we aggregate firm-level information from a matched employer-employee database to the municipal level and use a firm-level financial database. These datasets are from Statistics Portugal (INE).

Our municipal-level data comes from Quadros de Pessoal (QP). QP is based upon a mandatory survey submitted annually to the Portuguese Ministry of Employment and Social Security by firms with at least one employee. These data include information on an average 227,000 firms per year, covering virtually all the firms in the Portuguese private sector, but omit the self-employed workers. Firms annually report their entry year, location, industry, number of employees, number of establishments, initial capital, ownership structure, and sales. From QP, we select all new ventures with at least one paid employee, established between 2004 and 201199 operating in the

${ }^{7}$ Our results are robust considering the full sample of municipalities that did not change the tax rate. The results are presented on Table 8

${ }^{8}$ The first municipal elections under democratic rule took place in 1976 and, since then, local government's competencies have increased substantially. They are responsible for the promotion of education, health, communication, and culture and managing the funds from the European Union and central government.

${ }^{9}$ The QP data record the year of firm entry, which we use to calculate the firm age. In cases where the firm employs workers whose firm accession year is prior to the recorded firm entry year, we use the earlier year for our measure of firm entry. 
manufacturing and service sectors. Accordingly, we also exclude from our analysis start-ups operating in non-profit sectors and start-ups owned by any percentage by the government. In addition, we exclude from our sample firms with no sales for the entire period.

We supplement these data with information from other sources. Information on municipal socio-demographic and economic characteristics was retrieved from Statistics Portugal (INE). Data on local expenditures was obtained from the General Directorate for Local Authority's (Direcção-Geral das Autarquias Locais, DGAL) website and the set of political characteristics and electoral results was constructed based on data obtained from the General Directorate for Internal Affairs' (Direção-Geral da Administração Interna, DGAI).

With QP data, we compute firm entry and job creation rates at the municipal-level for 278 mainland Portuguese municipalities for the period between 2004-2011 ${ }^{10}$ Entry rate is measured by the number of entrants relative to the number of firms in existence at the beginning of the period ${ }^{11}$ We use a similar approach for job creation rate, by computing the number of jobs created by start-ups relative to the workforce at the beginning of the period. Both outcomes variables are computed separately for the manufacturing and service sectors ${ }^{12}$

fig:pt plots the evolution of the average entry rates separately for the manufacturing and services sectors. The figures depict an increasing pattern of firm entry until 2007, followed by downward trend onwards for both industries. For the manufacturing sector, the treatment group experienced higher average birth rates than the comparison counterpart in the pre-treatment period. However, after the reform, the pattern clearly changed. For both manufacturing and service entry rates, our graphical inspection does not seem to show an evolution capable of undermining the parallel trends' assumption. Nevertheless, this assumption will be explicitly tested with the event studies in the results section.

tab:stats presents the summary statistics on municipality's characteristics. The sample contains 1,024 observations. Before 2008, the average entry rate for manufacturing start-ups in the treated and control groups were $4.3 \%$ and $4.7 \%$, respectively. After 2008, these number reduced to $3.4 \%$ and $3.1 \%$, respectively.

Our firm-level data comes from Sistema de Contas Integrado da Empresa (SCIE), an annual firm-level financial database, collected by Statistics Portugal (INE) covering an extensive list of accounting variables (about 80 for the period 2004-2009 and 262 for 2010-2012). The database integrates information from Inquérito Anual às Empresas (IEH) and from tax information from Autoridade Tributária (TA). Currently, its main data source is the Informação Empresarial Simplificada(IES3). Every year, firms report their sales, number of employees, assets, debt, equity and capital expenditures. In spite of being a mandatory survey, firms nonetheless sometimes fail to report financial information in some of the years. In these cases, we linearly interpolate the firm's sales, debt and capital expenditures between the surrounding years with reported firm information ${ }^{13}$ Therefore, this database allow us to collect information on start-up's capital expenditures and financial structure.

From SCIE, we select all new ventures established between 2004 and 2011 and impose the same previous restrictions. Additionally, we ensure that start-ups report their debt, sales and capital investments on the entry year. Then, we retrieve start-up's financial information in the next five years.

\footnotetext{
${ }^{10}$ There are 308 municipalities in Portugal. We exclude 30 municipalities in the autonomous regions of Azores and Madeira because of their different institutional background and 22 municipalities in mainland Portugal because they charged a tax rate lower than $0.3 \%$ before the reform. As a robustness check, we run all empirical analyses considering the full sample of 278 municipalities.

${ }^{11}$ We use the ecological approach because we are attempting to explain why the reform affected the degree of entry varies between the manufacturing and service sectors. Alternatively, we could have used the labor market approach, standardizing the number of entrants with respect to the size of the work force Audretsch and Fritsch (1994).

${ }^{12}$ According to Classificação das Actividade Económicas (CAE) Revision 2.1, the manufacturing and service sectors include the industry codes between 15 and 36 and 50 to 93 , respectively.

${ }^{13} \mathrm{All}$ of our empirical analyses are run both including and excluding these interpolated data, with no substantive differences in the results.
} 


\section{Empirical Strategy}

\subsection{Municipal-level Analyses}

To estimate the effect of the tax reform on firm entry and job creation, we estimate the following difference-indifferences specification for municipality $i$ and year $t$, from 2004-2011:

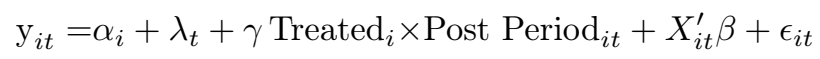

where $y$ are the outcome variables entry rate and job creation rate previously defined, $\alpha_{i}$ are the municipality fixed effects, $\lambda_{t}$ the time-period fixed effects, Treated is a binary indicator that takes value one if the municipality was forced to reduce the property tax rate, PostPeriod is a binary indicator that takes value one for the period 2009-2011, and $X_{i t}$ is a vector of socio-demographic, economic, and political characteristics at the municipal level. To control for socio-demographic factors, we include the age dependency ratio and the share of the workforce with a tertiary degree 14 To account for municipal income, we include the unemployment rate, measured as the ratio of resident population aged between 15 and 65 years old who is enrolled as unemployed in the Portuguese Institute of Employment and Professional Training (IEFP), and the consumption of electricity per capita. We also include the percentage of industrial area in a given municipality to consider possible synergies of exploring an integrated location with informational spillovers 15 We add two binary variables to account for the availability of local public goods: a dummy variable equalling one if there is at least one first instance court, and another dummy variable equalling one if there is at least one highway ramp in a given municipality 16 As for the political background, we include the total expenditure per capita in real terms, net of interest payments and two binary variables: a dummy variable equalling one if the Mayor and the Prime-Minister belong to the same political party, and another dummy variable equalling one if the Mayor holds a majority in the municipal council. Finally, to control for the effects of distinct political ideologies and agendas, we use the fraction of leftist mandates in the municipal council[17 We include the main determinants of new firm formation at the regional level to reduce possible endogeneity concerns in our regressions. The presence of heteroscedasticity and spatial correlation is controlled by clustering the standard errors by municipality since treatment varies at that level (Bertrand et al., 2004). The coefficient of interest in eq2 is $\gamma$.

There are three main challenges when assessing the causal impact of local taxation on entrepreneurship (Duranton et al. 2011). First, firms choose between a large set of possible number of heterogeneous locations. Many of these location characteristics are typically unobserved. To mitigate this issue, we include several municipal-level covariates. Moreover, we excluded from the control group twenty two municipalities with property tax rates below 0.3 in $2007{ }^{18}$ In principle, the preferences for public goods and tax rates of the high-tax controlled municipalities are more similar to the treated ones. Second, firms themselves are heterogeneous, and therefore, the sorting of firms according to their characteristics provides another source of bias. We compare entry rates for firms in two sectors of activity: manufacturing and services. Lastly, special features of the tax system may be endogenous to firm entry, which may lead to reverse causality. We circumvent this concern exploiting the unexpected quasi-natural

\footnotetext{
${ }^{14}$ Baptista and Mendonça 2010) show that a regional access to an educated workforce significantly impacts Portuguese firm location in specific sectors.

15 Gilbert et al. (2004) point out the expansion of industrial parks, science and technology incubators as an effective start-up oriented policy. Some examples of targeted-based policies include Zones Franches Urbaines (ZFU) in France (Mayer et al., 2015) and the federally financed New Industrial Policy for the states of Uttarakhand and Himachal Pradesh in India (Chaurey 2016).

16 Audretsch et al. (2017) highlight the relevance of highway provision for regional development in Portugal.

${ }^{17}$ In this regard, Reynolds et al. (1994) defended that right-wing conservatism tends to be related with a more resilient entrepreneurial culture.

${ }^{18}$ In the robustness section we show that considering these municipalities yields very similar estimates.
} 
experiment described in the previous subsection.

\subsection{Firm-level}

The firm-level sample constructed in Section 5 consists of new ventures established in treated and control municipalities. We use this sample, to evaluate the effect of the tax reform on firm's investment and funding decisions. Specifically, let $f$ be a new venture established in year $t$ in municipality $i$. Our estimating equation is:

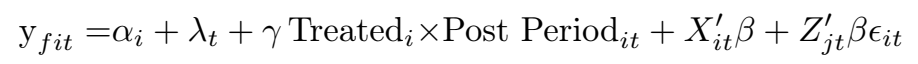

where $y$ are the firm-level outcome variables (short-term debt, capital expenditures and survival). $\alpha_{i}$ are the municipality fixed effects, $\lambda_{t}$ the time-period fixed effects and $X_{i t}$ is the previously considered municipal level vector of socio-demographic, economic, and political covariates. At the firm-level, we control for the logarithm of sales and for the logarithm of the number of employees. Again, $\gamma$ is our coefficient of interest.

\section{Main Results}

\subsection{Municipal-level Baseline Results}

Results of Ordinary Least of Squares (OLS) estimation of eq1 are presented in baseline separately for the manufacturing sector in Panel A and services sector in Panel B. Column (1) includes only municipality and year fixed effects. Column (2) adds specific regional (NUTS2) year fixed effects. Column (3) adds a vector of municipallevel control variables. Finally, in Column (4), we add specific population quartiles year fixed effects.

The estimates of $\gamma$ reported in Panel A baseline are positive and statistically significant at the level $5 \%$ level in Columns (1) and (2) and at the level 10\% level in Columns (3) and (4) even after including an extremely demanding set of controls and fixed effects ${ }^{19}$ The point estimate of 0.0065 increases to 0.0074 when we control for regional year fixed effects. After controlling for the socio-demographic, economic, and political context and population quartiles year fixed effects, the point estimate drops to 0.0063. The effect we report on baseline are of sizable magnitude for the manufacturing sector. Using the point estimates of Column (4), we find that municipalities that were forced to decreased the property tax rate exhibited a 0.63 percentage point increase in firm entry rate. Considering that before the reform, the average entry rate was $4.55 \%$, our estimate corresponds to a $14 \%$ increase in firm entry. In contrast, we find no statistically significant impact of the property tax reform in the service sector ${ }^{20}$

In jobcreation we run the same specifications to examine the impact of the reform on employment. In this case, the dependent variable in 1 is the number of jobs created by start-ups relative to the workforce at the beginning of the period. As expected, for the manufacturing sector (Panel A) the point estimates are positive but only statistically significant in Columns (1) and (2). Using the point estimates of Column (4), we find that municipalities that reduced the property tax rate exhibited a 0.5 percentage point increase in job creation. Once again, we find no statistically significant impact of the property tax reform in the service sector. Since most of the action is taking place for entry rates, we will focus on this outcome for the remaining of the municipal-level section.

\footnotetext{
${ }^{19}$ We run an alternative specification including the average real estate prices in the vector of controls. As pointed out by Alvarez and Pereira dos Santos (2019), the reform had a direct impact on real estate prices and therefore it constitutes a bad control in our setting. Nevertheless, if we include it, results remain very similar and are available from the authors' upon request.

${ }^{20}$ If we substitute entry rate by exit rates as our dependent variable, the results are not statistically significant and are available from the authors' upon request.
} 


\subsection{Internal Validity}

The identification strategy of our baseline results relies on two assumptions that we now discuss: (i) characteristics of the local areas must be balanced in treatment and comparison groups; and (ii) municipalities must be on parallel trends in the pre-treatment period.

With respect to the first requirement, we tackle it by performing tests of differences in the control variables in the pre-treatment period. These tests show significant socioeconomic differences between the treatment and control groups. However, when we run auxiliary regressions of the same observables on a series of fixed effects and Treated, these tests are able to capture most of the differences for these control variables, with the exception of the age dependency ratio and a binary indicator indicating that mayors had a majority in the Municipal Assembly. In both cases, however, the results where economically small. Results for both tests are displayed in tab:balance.

Regarding the assumption that the reduction on local property taxes in particular municipalities is not correlated with existing trends in firm formation or economic growth rate we execute three exercises. One common way to test this requirement is to compare the evolution of the different dependent variables in treated and comparison units during the pre-treatment and the treatment periods (Angrist and Pischke, 2009). As discussed, fig:pt portrays the mean evolution for the municipal-level outcomes. This graphical inspection does not provide evidence of distinct pre-treatment trends between the treatment and comparison groups capable of undermining our identification strategy.

In any case, we further study this assumption by implementing an event study design that has several advantages. First, we can test treatment exogeneity by examining pre-trends more carefully. In the absence of a pre-trend, the identifying assumption requires no systematic factors driving both the shock and the outcomes of interest. Second, the event study enables to evaluate the impact of the shock in the outcome variables in the very short-run. fig:eventstudy reports the event study for entry rates in Manufacturing and Services. This allows us to check the assumptions underlying the empirical approach as well as paint a more complete picture of the program's short-term dynamics. The interaction terms become significantly positive only after the year 2009. The results imply that in the first year of the reform, there is a statistically significant difference in manufacturing entry rates between the treated and control group. Results related to the services sector provide no evidence of an impact of the reform on entry rates.

Finally, we perform a falsification (placebo) test where we restrict the period of analysis between 2004 and 2007. The treatment and control groups remain the same but the post treatment period is set before the reform was implemented (2003-2007) in placebo. This exercise displays no statistical significant effects. Therefore, this further strengthens the interpretation of the results as being caused by this specific timing and scope of the property tax reform.

\subsection{Robustness Results}

Our first robustness exercise modifies eq1 to encompass an interaction with the imposed decrease of the tax rate. The treatment intensity effects are obtained by substituting Treated by Intensity, a non-binary indicator of how much the municipality was forced to decrease the property tax rate. The results, displayed in robint, yield very similar conclusions to our baseline.

We also present results for the full sample of Portuguese mainland samples in rob1. Therefore, this specification includes the twenty two municipalities with very low property tax rates in 2007. In the same table, we also consider our baseline results taking into account only single establishment firms which comprise the large majority of our sample. In both cases, results remain similar to the baseline. 
Furthermore, we compute three additional exercises in rob2. First, we drop 2008, the year when the reform was announced and implemented. Second, we remove the most severe crisis year from our sample (i.e., 2011) when Portugal requested an assistance program to the European Commission, the European Central Bank, and the International Monetary Fund. The goal is to dismiss concerns that our result is being driven by this event. Finally, we compute a geographical exercise dropping all municipalities in the Atlantic coast. These findings further support with our baseline specifications.

\subsection{Heterogeneity Results}

In this subsection, we distinguish our baseline results for entry rates between high and low technology new ventures. According to OECD (2002), technology-based industries can be divided into high-technology industries (pharmaceuticals, office and computing machinery, radio, TV and communication equipment, medical, precision and optical equipment, aircraft and spacecraft); medium-high-technology industries (chemicals excluding pharmaceuticals, machinery and equipment, electrical machinery and apparatus, motor vehicles and trailers, railroad and transport equipment) and medium-low-technology industries (coke, refined petroleum products and nuclear fuel, rubber and plastic products, other non-metallic mineral products, basic metals, fabricated metal products except machinery and equipment, building and repairing ships and boats) and low-technology industries (food products, beverage and tobacco, textile and textile products, leather and footwear, wood, pulp, paper products, printing and publishing and publishing, and recycling). The results depicted in heterogeneity allows us to conclude that our results are being driven by low technology manufacturing firms. Zooming in the manufacturing sector, fig:sectors shows that not all industries were equally affected by the reform.

\subsection{Alternative Mechanisms and Firm-level Results}

We focus our attention on different alternative mechanisms that can explain the results. One of them is that the reduced tax property tax bill acts as a positive wealth shock for the local area. In such a case, overall increased consumer demand would be driving firm entry rates for some entrepreneurs in treated units. Unfortunately, there is no GDP data at the municipal level to evaluate this. We thus test this possibility by substituting the outcome variable in eq1 by other proxies of the economic cycle such as the total ATM cash withdrawal volume and the number of ATM withdrawals. The results are reported in demand and are not statistically different from zero ${ }^{21}$

Another concern is warranted if municipalities are reacting to the negative shock in their public finances by changing their spending profile and decreasing the level of public good provision. Nevertheless, when we consider primary expenditures as the dependent variable in eq1, the results presented in columns (1) and (2) of reaction show no statistically significant impact. In addition, we test whether local authorities tried to increase business tax revenues. The findings in columns (3) and (4) of reaction, although positive, are also not statistically significantly different from zero.

Finally, we look into a panel dataset of all new ventures to study how the property tax reform affected their survival, growth, capital investments' decisions. For the remaining of our paper, odd columns include a vector of firm-level controls, municipality, year, and NUTS 2 specific year fixed effects. Even columns add municipal-level covariates and specific population quartile dummies year fixed effects.

First, we run a linear probability model considering the likelihood of a start-up surviving one, three or five years. survival advances the results. Our findings suggest that, for start-ups in both manufacturing and services sector, the probability of surviving increases about $3 \%$ to $5 \%$ in the three periods.

${ }^{21}$ The same no-result holds if we use the electricity consumption per capita as the dependent variable. 
Second, we consider differences in financing the activity in the entry year in debt0. The results show that firms in manufacturing start with substantially higher leverage in the short run than similar firms in the comparison group.

\section{Concluding remarks}

Entrepreneurial activity is considered to be an important driver of innovation and economic growth. Understanding whether financial constraints significantly deters firm entry has important policy implications as governments tend to subsidize lending to small firms based on the premise that these are indeed constrained. Our study contributes to this debate by taking advantage of quasi-natural reform that changed the property tax rate to a subset of Portuguese municipalities.

We find that municipalities that were forced to decrease their property tax rate experienced higher entry rates in the manufacturing sector vis-à-vis municipalities that had a property tax rate at or below the new upper bound. The results are not significant for the service sector and are robust to a series of exercises and placebo tests.

We further discuss and test alternative mechanisms that can explain our baseline results. These examinations provide a compelling picture regarding the fact that it seems to be the shock to the wealth of the entrepreneur, via the collateral channel, that is driving observed results. We find that manufacturing start-ups established in treated municipalities are more likely to increase their amount of short-term debt. These findings suggest that the value of housing collateral is important to entrepreneurship in sectors that require some start-up capital such low-technological start-ups. Regarding firm-level evidence, ventures in treated areas had a significantly higher

probability of surviving in the short to medium-run. Moreover, the increase in investment in buildings seems to be compensated by a further increase in debt, especially in the short-run. 


\section{References}

Angrist, J. D. and J.-S. Pischke (2009). Mostly harmless econometrics: An empiricist's companion. Princeton: Princeton University Press.

Audretsch, D. B., D. Dohse, and J. P. dos Santos (2017). Do toll-free highways foster firm formation and employment growth? results from a quasi-natural experiment. Technical report, Kiel Working Paper.

Audretsch, D. B. and M. Fritsch (1994, feb). On the measurement of entry rates. Empirica 21 (1), $105-113$.

Baptista, R. and J. Mendonça (2010). Proximity to knowledge sources and the location of knowledge-based start-ups. The Annals of Regional Science 45(1), 5-29.

Bertrand, M., E. Duflo, and S. Mullainathan (2004). How much should we trust differences-in-differences estimates? The Quarterly Journal of Economics 119(1), 249-275.

Blanchflower, D. G. and A. J. Oswald (1998). What makes an entrepreneur? Journal of Labor Economics 16(1), 26-60.

Block, J. (2016). Corporate income taxes and entrepreneurship. IZA World of Labor.

Burke, A. E., F. R. FitzRoy, and M. A. Nolan (2000). When less is more: distinguishing between entrepreneurial choice and performance. Oxford Bulletin of Economics and Statistics 62(5), 565-587.

Chaurey, R. (2016). Location-based tax incentives: Evidence from india. Journal of Public Economics.

Cressy, R. (1996). Are business startups debt-rationed? The Economic Journal, 1253-1270.

Dunn, T. and D. Holtz-Eakin (2000). Financial capital, human capital, and the transition to self-employment: Evidence from intergenerational links. Journal of labor economics 18(2), 282-305.

Duranton, G., L. Gobillon, and H. G. Overman (2011). Assessing the effects of local taxation using microgeographic data. The Economic Journal 121(555), 1017-1046.

Evans, D. S. and B. Jovanovic (1989). An estimated model of entrepreneurial choice under liquidity constraints. Journal of Political Economy 97(4), 808-827.

Fairlie, R. W. and H. A. Krashinsky (2012). Liquidity constraints, household wealth, and entrepreneurship revisited. Review of Income and Wealth 58(2), 279-306.

Gilbert, B. A., D. B. Audretsch, and P. P. McDougall (2004). The emergence of entrepreneurship policy. Small Business Economics 22(3-4), 313-323.

Holtz-Eakin, D., D. Joulfaian, and H. S. Rosen (1994). Sticking it out: Entrepreneurial survival and liquidity constraints. Journal of Political Economy 102(1), 53-75.

Hurst, E. and A. Lusardi (2004). Liquidity constraints, household wealth, and entrepreneurship. Journal of Political Economy 112(2), 319-347.

Hurst, E. and B. W. Pugsley (2011). What do small businesses do? Brookings Papers on Economic Activity (2).

Lindh, T. and H. Ohlsson (1996). Self-employment and windfall gains: evidence from the swedish lottery. The Economic Journal, 1515-1526.

Mayer, T., F. Mayneris, and L. Py (2015). The impact of urban enterprise zones on establishment location decisions and labor market outcomes: evidence from france. Journal of Economic Geography, lbv035.

Meza, D. d. and D. Webb (1999). Wealth, enterprise and credit policy. The Economic Journal 109(455), 153-163.

Neubig, T. S., R. J. Cline, and A. D. Phillips (2006). Total state and local business taxes: Nationally 1980-2005, by state 2002-2005. State Tax Notes 40(5).

Nykvist, J. (2008). Entrepreneurship and liquidity constraints: Evidence from sweden. Scandinavian Journal of Economics 110(1), 23-43.

Peralta, S. and J. Pereira dos Santos (2018). Who seeks re-election: Local fiscal restraints and political selection. Technical report, Gabinete de Estratégia e Estudos, Ministério da Economia.

Reynolds, P., D. J. Storey, and P. Westhead (1994). Cross-national comparisons of the variation in new firm formation rates. Regional Studies 28(4), 443-456.

Xu, B. (1998). A reestimation of the evans-jovanovic entrepreneurial choice model. Economics Letters 58(1), 91-95. 


\section{Figures}

Figure 1: Treated and Control Municipalities

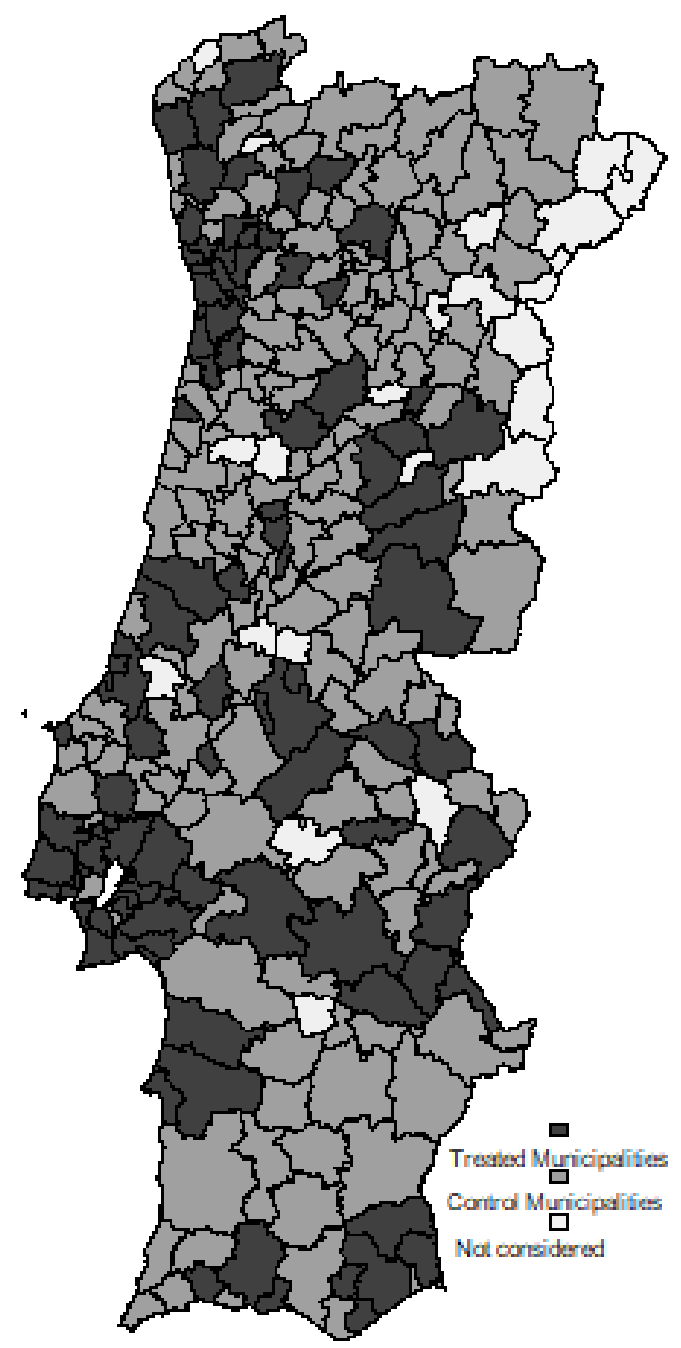

Notes: The figure plots the municipalities who were forced to decrease the tax rate to $0.4 \%$ (treatment group) and the municipalities that charged a tax rate between $0.3 \%$ and $0.4 \%$ before the reform (control group).The remaining municipalities charged a tax rate bellow $0.3 \%$ and they were not included in the main analysis. 
Figure 2: Evolution of Entry Rates
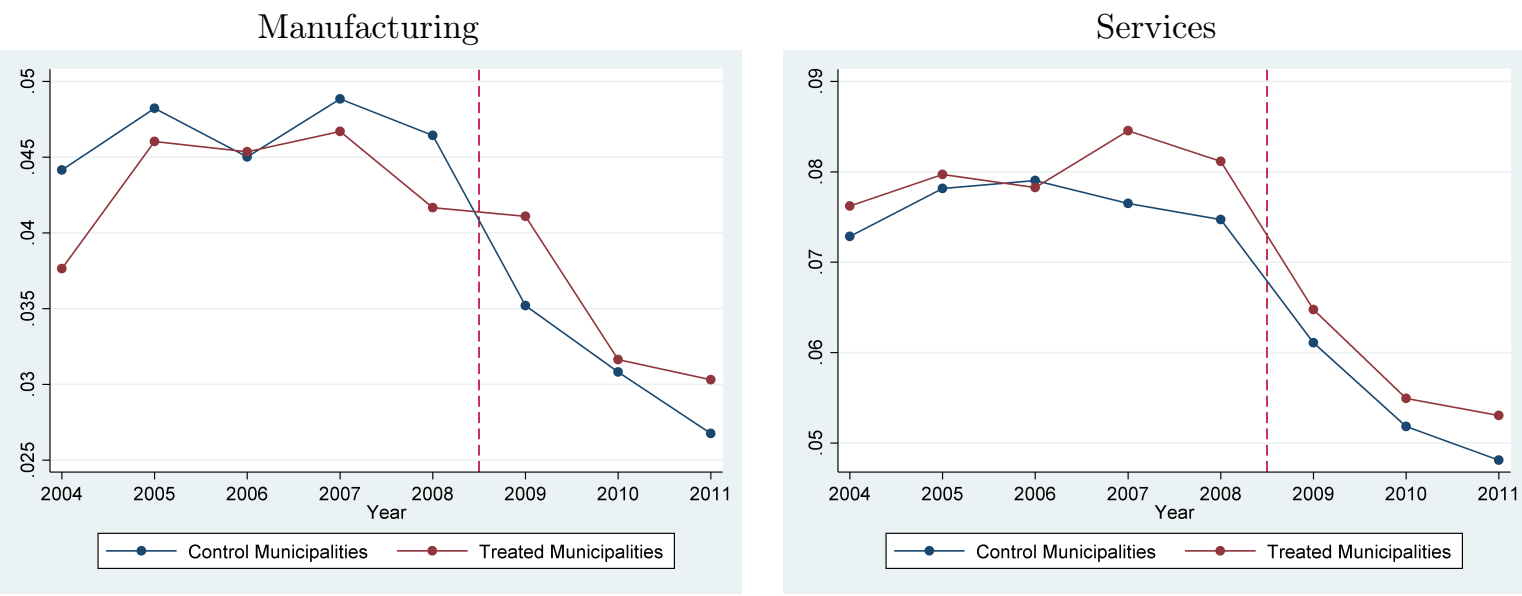

Notes: The figure plots the evolution of the average entry rates for treatment and control groups over the period 2004-2011, separately for the manufacturing and service sectors. 
Figure 3: Evolution of Entry Rates
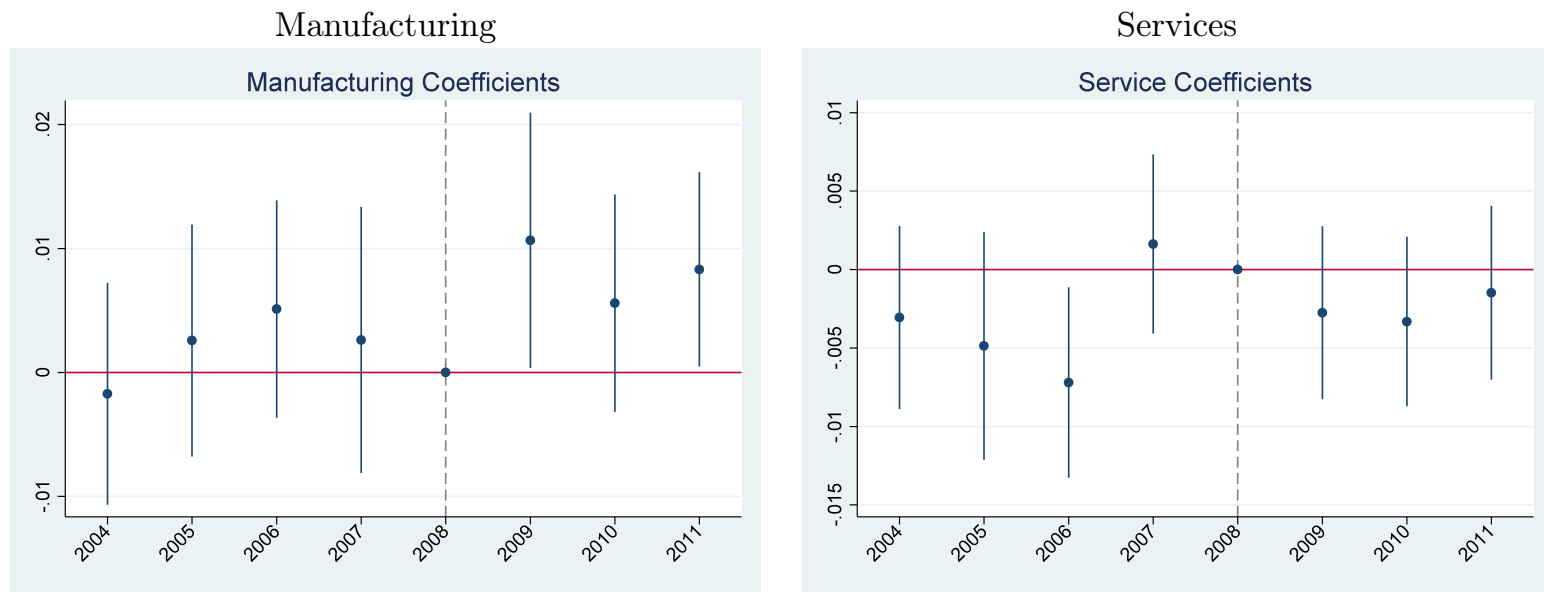

Notes: 90\% Confidence Levels. Standard errors are clustered at the municipal level.

Figure 4: Heterogeneity Results - Manufacturing Sectors

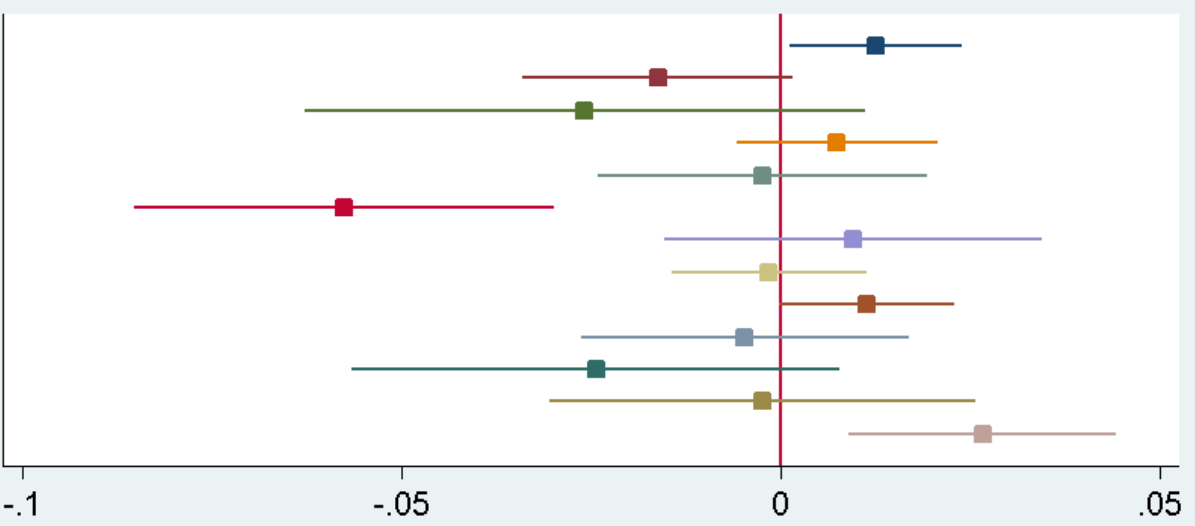

$-.1$

Food, Beverage and Tobacco

- Leather Products

- Paper Products

- Rubber and Plastic Products

- Metal Products

- Electrical and Optical Equipment

- Furniture and Others
- Textile Products

- Wood Products

- Chemical Products

Nonmetallic Mineral Products

- Machinery and Equipments

- Transport Equipment

Notes: 90\% Confidence Levels. Standard errors are clustered at the municipal level. 


\section{Tables}

Table 1. Property Tax Rates: Minimum and Maximum Values

\begin{tabular}{ccc}
\hline Year & \multicolumn{2}{c}{ Reassessed (IMI) } \\
& Min & Max \\
\hline $2003-2007$ & $0.20 \%$ & $0.50 \%$ \\
$2008-2011$ & $0.20 \%$ & $0.40 \%$ \\
\hline
\end{tabular}

In this study, we focus on the reassessed urban properties tax rate reform.

Source: Portuguese tax authority

Table 2. Summary Statistics for the Municipal-Level Analysis

\begin{tabular}{lccccc}
\hline Variable & Obs. & Mean & Std. Dev. & Min & Max \\
\hline Dependent variables: & & & & & \\
Manufacturing entry rate & 2048 & 0.0404 & 0.0352 & 0 & 0.3077 \\
Services entry rate & 2048 & 0.0692 & 0.0255 & 0 & 0.2188 \\
\hline Controls: & & & & & \\
age dependency ratio & 2048 & 58.224 & 11.806 & 38.239 & 108.789 \\
workforce with a tertiary degree & 2048 & 0.067 & 0.033 & 0.014 & 0.302 \\
same political party dummy & 2048 & 0.402 & 0.490 & 0.000 & 1.000 \\
highways & 2048 & 0.574 & 0.495 & 0.000 & 1.000 \\
unemployment rate & 2048 & 6.667 & 2.335 & 1.439 & 16.933 \\
consumption of electricity pc & 2048 & 4435.365 & 4995.522 & 1372.587 & 66560.670 \\
primary expenditure pc & 2048 & 0.923 & 0.459 & 0.2601 & 4.633 \\
first instance court dummy & 2048 & 0.758 & 0.428 & 0.000 & 1.000 \\
percentage of industrial area & 2048 & 0.015 & 0.023 & 0.000 & 0.150 \\
share of leftist mandates & 2048 & 0.556 & 0.255 & 0.000 & 1.000 \\
\hline Triple diff-in-diff: & & & & & \\
share full owners & 278 & 0.168 & 0.092 & 0.015 & 0.531 \\
share partial owners & 278 & 0.666 & 0.163 & 0.282 & 0.970 \\
share renters & 278 & 0.170 & 0.094 & 0.015 & 0.521 \\
\hline
\end{tabular}

This table presents the summary statistics for the municipal level sample, which we use to evaluate the reform effects on the entry and job creation rates. The sample period is 2004 and 2011. 
Table 3. Baseline Results - Firm Entry Rates

\begin{tabular}{|c|c|c|c|c|}
\hline & \multicolumn{4}{|c|}{ Entry Rates } \\
\hline & (1) & $(2)$ & $(3)$ & $(4)$ \\
\hline \multirow{3}{*}{ Treated $\times$ Post Period } & \multicolumn{4}{|c|}{ Panel A. Manufacturing } \\
\hline & $0.0065^{* *}$ & $0.0074^{* *}$ & $0.0060^{*}$ & $0.0063^{*}$ \\
\hline & $(0.0029)$ & $(0.0032)$ & $(0.0033)$ & $(0.0035)$ \\
\hline \multirow[t]{2}{*}{ Adjusted $\mathrm{R}^{2}$} & 0.0480 & 0.0440 & 0.0486 & 0.0533 \\
\hline & \multicolumn{4}{|c|}{ Panel B. Services } \\
\hline \multirow[t]{2}{*}{ Treated $\times$ Post Period } & 0.0002 & 0.0016 & 0.0026 & 0.0016 \\
\hline & $(0.0021)$ & $(0.0023)$ & $(0.0025)$ & $(0.0026)$ \\
\hline Adjusted $\mathrm{R}^{2}$ & 0.254 & 0.252 & 0.256 & 0.258 \\
\hline Municipality FE & $\checkmark$ & $\checkmark$ & $\checkmark$ & $\checkmark$ \\
\hline Year FE & $\checkmark$ & & & \\
\hline Nuts $2 \times$ Year FE & & $\checkmark$ & $\checkmark$ & $\checkmark$ \\
\hline Controls & & & $\checkmark$ & $\checkmark$ \\
\hline Pop quartiles $\times$ Year FE & & & & $\checkmark$ \\
\hline
\end{tabular}

Notes: $\mathrm{N}=2048$. The vector of socio-demographic, economic, and political controls includes the age dependency ratio, the share of the workforce with a tertiary degree, the unemployment rate, the consumption of electricity per capita, the percentage of industrial area, a first instance court dummy, a highway dummy, a same political party dummy, a majority dummy, the share of leftist mandates, and the primary municipal expenditure per capita. Standard errors in parenthesis are clustered at the municipal level. Stars indicate significance levels of $10 \%(*)$, $5 \%(* *)$, and $1 \%(* * *)$. 
Table 4. Baseline Results - Job Creation Rates

\begin{tabular}{|c|c|c|c|c|}
\hline & \multicolumn{4}{|c|}{ Job Creation Rates } \\
\hline & (1) & $(2)$ & $(3)$ & $(4)$ \\
\hline \multirow{3}{*}{ Treated $\times$ Post Period } & \multicolumn{4}{|c|}{ Panel A. Manufacturing } \\
\hline & $0.008 * \bar{*}$ & $0.008^{*}$ & 0.007 & 0.005 \\
\hline & $(0.004)$ & $(0.005)$ & $(0.005)$ & $(0.004)$ \\
\hline \multirow[t]{2}{*}{ Adjusted $\mathrm{R}^{2}$} & 0.0137 & 0.0105 & 0.0130 & 0.0165 \\
\hline & \multicolumn{4}{|c|}{$\underline{\text { Panel B. Services }}$} \\
\hline \multirow[t]{2}{*}{ Treated $\times$ Post Period } & 0.003 & 0.003 & 0.003 & 0.001 \\
\hline & $(0.002)$ & $(0.002)$ & $(0.002)$ & $(0.002)$ \\
\hline Adjusted $\mathrm{R}^{2}$ & 0.0808 & 0.0741 & 0.0743 & 0.0758 \\
\hline Municipality FE & $\checkmark$ & $\checkmark$ & $\checkmark$ & $\checkmark$ \\
\hline Year FE & $\checkmark$ & & & \\
\hline Nuts $2 \times$ Year FE & & $\checkmark$ & $\checkmark$ & $\checkmark$ \\
\hline Controls & & & $\checkmark$ & $\checkmark$ \\
\hline Pop quartiles $\times$ Year FE & & & & $\checkmark$ \\
\hline
\end{tabular}

Notes: $\mathrm{N}=2048$. The vector of socio-demographic, economic, and political controls includes the age dependency ratio, the share of the workforce with a tertiary degree, the unemployment rate, the consumption of electricity per capita, the percentage of industrial area, a first instance court dummy, a highway dummy, a same political party dummy, a majority dummy, the share of leftist mandates, and the primary municipal expenditure per capita. Standard errors in parenthesis are clustered at the municipal level. Stars indicate significance levels of $10 \%(*)$, $5 \%(* *)$, and $1 \%(* * *)$. 
Table 5. Balance Tests

\begin{tabular}{lcccc}
\hline & Treatment & Control & Diff. (Std. Err.) & Treated (Std. Dev.) \\
\hline Dependent variables: & & & & $-0.002(0.002)$ \\
Manufacturing Entry Rate & 0.043 & 0.047 & $-0.003(0.002)$ & $0.002(0.002)$ \\
Service Entry Rate & 0.08 & 0.076 & $0.004^{* *}(0.002)$ & $0.061(0.058)$ \\
Controls: & & & & $-2.199^{*}(1.168)$ \\
lnPopulation & 10.487 & 9.552 & $0.935^{* * *}(0.137)$ & $0.006(0.004)$ \\
age dependency ratio & 53.02 & 60.968 & $-7.948^{* * *}(1.413)$ & $-0.057(0.046)$ \\
percentage of industrial area & 0.024 & 0.01 & $0.014^{* * *(0.003)}$ & $-0.0002(0.004)$ \\
first instance court dummy & 0.819 & 0.76 & $0.059(0.052)$ & $0.0704^{*}(0.038)$ \\
workforce with tertiary degree & 0.07 & 0.056 & $0.014^{* * *}(0.004)$ & $0.048(0.039)$ \\
majority & 0.887 & 0.89 & $-0.003(0.034)$ & $0.0366(0.029)$ \\
same political party dummy & 0.419 & 0.383 & $0.036(0.041)$ & $1099.981(1086.289)$ \\
share of leftist mandates & 0.578 & 0.535 & $0.043(0.032)$ & $0.171(0.261)$ \\
consumption of electricity pc & 5116.214 & 3852.597 & $1263.617^{*}(724.820)$ & $0.024(0.032)$ \\
unemployment rate & 6.207 & 6.038 & $0.169(0.256)$ & $0.001(0.055)$ \\
primary expenditure pc & 0.77 & 0.941 & $-0.171^{* * *}(0.052)$ & $\checkmark$ \\
highway dummy & 0.721 & 0.478 & $0.243^{* * *}(0.060)$ & $\checkmark$ \\
\hline Municipality FE & & & & $\checkmark$ \\
Nuts $2 \times$ Year FE & & & & $\checkmark$ \\
Controls & & & & $\checkmark$ \\
Pop quartiles $\times$ Year FE & & & & \\
\hline
\end{tabular}

Notes: Standard errors in parenthesis are clustered at the municipal level. Stars indicate significance levels of $10 \%$ $\left(^{*}\right), 5 \%(* *)$, and $1 \%(* * *)$. 
Table 6. Falsification Test (Placebo)

\begin{tabular}{|c|c|c|}
\hline & \multicolumn{2}{|c|}{ Entry Rates } \\
\hline & $(1)$ & $(2)$ \\
\hline \multirow{3}{*}{ Treated $\times$ Post Period } & Panel A & inufacturing \\
\hline & 0.0034 & 0.0019 \\
\hline & $(0.0048)$ & $(0.0052)$ \\
\hline \multirow[t]{2}{*}{ Adjusted $\mathrm{R}^{2}$} & 0.00628 & 0.00825 \\
\hline & Pane & Services \\
\hline \multirow{2}{*}{ Treated $\times$ Post Period } & 0.0002 & -0.0029 \\
\hline & $(0.0027)$ & $(0.0028)$ \\
\hline Adjusted $\mathrm{R}^{2}$ & 0.00857 & 0.0232 \\
\hline Municipality FE & $\checkmark$ & $\checkmark$ \\
\hline Nuts $2 \times$ Year FE & $\checkmark$ & $\checkmark$ \\
\hline Controls & & $\checkmark$ \\
\hline Pop quartiles $\times$ Year FE & & $\checkmark$ \\
\hline
\end{tabular}

Notes: $N=1112$. Standard errors in parenthesis are clustered at the municipal level. Odd (even) specifications correspond to column (2) (column (4)) of baseline. The Post Period, in this specification, is set to years 2006 and 2007. The vector of socio-demographic, economic, and political controls includes the age dependency ratio, the share of the workforce with a tertiary degree, the unemployment rate, the consumption of electricity per capita, the percentage of industrial area, a first instance court dummy, a highway dummy, a same political party dummy, a majority dummy, the share of leftist mandates, and the primary municipal expenditure per capita. Stars indicate significance levels of $10 \%(*), 5 \%(* *)$, and $1 \%(* * *)$. 
Table 7. Robustness Checks - Intensity of Treatment

\begin{tabular}{lcc}
\hline & \multicolumn{2}{c}{ Entry Rates } \\
\cline { 2 - 3 } & \multicolumn{1}{c}{ Panel A. Manufacturing } \\
\cline { 2 - 3 } Intensity $\times$ Post Period & $0.0837^{* *}$ & $0.0707^{*}$ \\
& $(0.0389)$ & $(0.0419)$ \\
Adjusted R & & $(1)$ \\
& 0.0441 & 0.0534 \\
Intensity $\times$ Post Period & 0.0151 & 0.0153 \\
& $(0.0259)$ & $(0.0291)$ \\
Adjusted R & Panel B. Services \\
\hline Municipality FE & 0.252 & 0.258 \\
Nuts $2 \times$ Year FE & $\checkmark$ & $\checkmark$ \\
Controls & $\checkmark$ & $\checkmark$ \\
Pop quartiles $\times$ Year FE & & $\checkmark$ \\
\hline
\end{tabular}

Notes: $\mathrm{N}=2048$. Standard errors in parenthesis are clustered at the municipal level. Odd (even) specifications correspond to column (2) (column (4)) of baseline. The vector of socio-demographic, economic, and political controls includes the age dependency ratio, the share of the workforce with a tertiary degree, the unemployment rate, the consumption of electricity per capita, the percentage of industrial area, a first instance court dummy, a highway dummy, a same political party dummy, a majority dummy, the share of leftist mandates, and the primary municipal expenditure per capita. Stars indicate significance levels of $10 \%\left({ }^{*}\right), 5 \%\left({ }^{* *}\right)$, and $1 \%(* * *)$. 
Table 8. Robustness Checks - Different Samples

\begin{tabular}{|c|c|c|c|c|}
\hline & \multicolumn{4}{|c|}{ Entry Rates } \\
\hline & \multicolumn{2}{|c|}{ Full Sample } & \multicolumn{2}{|c|}{ Single Estab Firms } \\
\hline & $(1)$ & $(2)$ & $(3)$ & $(4)$ \\
\hline \multirow{3}{*}{ Treated $\times$ Post Period } & \multicolumn{4}{|c|}{ Panel A. Manufacturing } \\
\hline & $0.0076^{* *}$ & $0.0061^{*}$ & $0.0084^{* *}$ & $0.0079^{* *}$ \\
\hline & $(0.0032)$ & $(0.0037)$ & $(0.0034)$ & $(0.0037)$ \\
\hline \multirow[t]{2}{*}{ Adjusted $\mathrm{R}^{2}$} & 0.0435 & 0.0475 & 0.0335 & 0.0395 \\
\hline & \multicolumn{4}{|c|}{$\underline{\text { Panel B. Services }}$} \\
\hline \multirow[t]{2}{*}{ Treated $\times$ Post Period } & 0.0007 & $0 . \overline{0030}$ & 0.0019 & 0.0019 \\
\hline & $(0.0021)$ & $(0.0024)$ & $(0.0024)$ & $(0.0028)$ \\
\hline Adjusted $\mathrm{R}^{2}$ & 0.243 & 0.245 & 0.230 & 0.238 \\
\hline Municipality FE & $\checkmark$ & $\checkmark$ & $\checkmark$ & $\checkmark$ \\
\hline Nuts $2 \times$ Year FE & $\checkmark$ & $\checkmark$ & $\checkmark$ & $\checkmark$ \\
\hline Controls & & $\checkmark$ & & $\checkmark$ \\
\hline Pop quartiles $\times$ Year FE & & $\checkmark$ & & $\checkmark$ \\
\hline
\end{tabular}

Notes: $\mathrm{N}=2224$ for the Full Sample. $\mathrm{N}=2048$ for the remaining specifications. Odd (even) models correspond to column (2) (column (4)) of baseline. The vector of socio-demographic, economic, and political controls includes the age dependency ratio, the share of the workforce with a tertiary degree, the unemployment rate, the consumption of electricity per capita, the percentage of industrial area, a first instance court dummy, a highway dummy, a same political party dummy, a majority dummy, the share of leftist mandates, and the primary municipal expenditure per capita. Standard errors in parenthesis are clustered at the municipal level. Stars indicate significance levels of $10 \%(*), 5 \%(* *)$, and $1 \%(* * *)$. 
Table 9. Robustness Checks - Time and Space

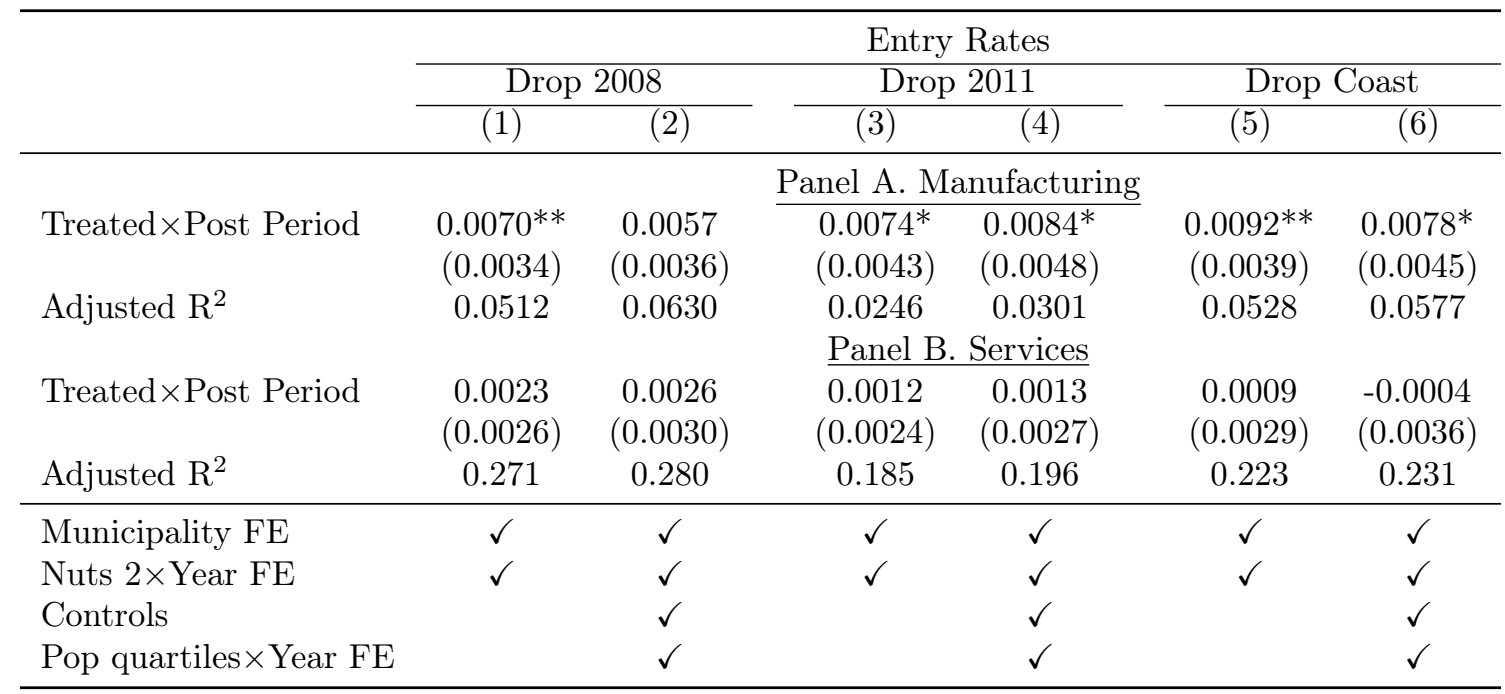

Notes: $\mathrm{N}=1792$ for the first two specifications. $\mathrm{N}=1632$ in the last specification. Odd (even) models correspond to column (2) (column (4)) of baseline. The vector of socio-demographic, economic, and political controls includes the age dependency ratio, the share of the workforce with a tertiary degree, the unemployment rate, the consumption of electricity per capita, the percentage of industrial area, a first instance court dummy, a highway dummy, a same political party dummy, a majority dummy, the share of leftist mandates, and the primary municipal expenditure per capita. Standard errors in parenthesis are clustered at the municipal level. Stars indicate significance levels of $10 \%(*), 5 \%(* *)$, and $1 \%(* * *)$. 
Table 10. Heterogeneity Results - High vs. Low Technology

\begin{tabular}{|c|c|c|c|c|}
\hline & \multicolumn{4}{|c|}{ Entry Rates } \\
\hline & \multicolumn{2}{|c|}{ High Tech } & \multicolumn{2}{|c|}{ Low Tech } \\
\hline & $(1)$ & $(2)$ & $(3)$ & (4) \\
\hline & \multicolumn{4}{|c|}{ Panel A. Manufacturing } \\
\hline Treated $\times$ Post Period & $\begin{array}{c}-0.0044 \\
(0.0153)\end{array}$ & $\begin{array}{l}-0.0051 \\
(0.0162)\end{array}$ & $\begin{array}{c}0.0083^{* *} \\
(0.0033)\end{array}$ & $\begin{array}{c}0.0072^{* *} \\
(0.0036)\end{array}$ \\
\hline Adjusted $\mathrm{R}^{2}$ & 0.0107 & 0.0111 & 0.0440 & 0.0556 \\
\hline Treated $\times$ Post Period & $\begin{array}{c}0.0057 \\
(0.0083) \\
0.0184\end{array}$ & $\begin{array}{c}\text { Panel } \\
0.0110 \\
(0.0087)\end{array}$ & $\begin{array}{c}\text { ervices } \\
0.0012 \\
(0.0023) \\
0.248\end{array}$ & $\begin{array}{c}0.0005 \\
(0.0027) \\
0.259\end{array}$ \\
\hline Mugused th & & & & \\
\hline Municipality FE & $\checkmark$ & $\checkmark$ & $\checkmark$ & $\checkmark$ \\
\hline Nuts $2 \times$ Year FE & $\checkmark$ & $\checkmark$ & $\checkmark$ & $\checkmark$ \\
\hline Controls & & $\checkmark$ & & $\checkmark$ \\
\hline Pop quartiles $\times$ Year FE & & $\checkmark$ & & $\checkmark$ \\
\hline
\end{tabular}

Notes: Standard errors in parenthesis are clustered at the municipal level. Odd (even) specifications correspond to column (2) (column (4)) of baseline. The vector of socio-demographic, economic, and political controls includes the age dependency ratio, the share of the workforce with a tertiary degree, the unemployment rate, the consumption of electricity per capita, the percentage of industrial area, a first instance court dummy, a highway dummy, a same political party dummy, a majority dummy, the share of leftist mandates, and the primary municipal expenditure per capita. Stars indicate significance levels of $10 \%(*), 5 \%(* *)$, and $1 \%(* * *)$. 
Table 11. Demand

\begin{tabular}{|c|c|c|c|c|}
\hline & \multicolumn{2}{|c|}{$\ln ($ ATM Withdrawal Value) } & \multicolumn{2}{|c|}{$\ln$ (Number of ATM Withdrawals) } \\
\hline & $(1)$ & $(2)$ & $(3)$ & $(4)$ \\
\hline Treated $\times$ Post Period & -0.0177 & -0.0120 & -0.0126 & -0.0095 \\
\hline & $(0.0154)$ & $(0.0161)$ & $(0.0158)$ & $(0.0162)$ \\
\hline Adjusted $\mathrm{R}^{2}$ & 0.323 & 0.326 & 0.229 & 0.236 \\
\hline Municipality FE & $\checkmark$ & $\checkmark$ & $\checkmark$ & $\checkmark$ \\
\hline Nuts $2 \times$ Year FE & $\checkmark$ & $\checkmark$ & $\checkmark$ & $\checkmark$ \\
\hline Controls & & $\checkmark$ & & $\checkmark$ \\
\hline Pop quartiles $\times$ Year FE & & $\checkmark$ & & $\checkmark$ \\
\hline
\end{tabular}

Notes: $\mathrm{N}=2048$. Odd (even) models correspond to column (2) (column (4)) of baseline. The vector of socio-demographic, economic, and political controls includes the age dependency ratio, the share of the workforce with a tertiary degree, the unemployment rate, the consumption of electricity per capita, the percentage of industrial area, a first instance court dummy, a highway dummy, a same political party dummy, a majority dummy, the share of leftist mandates, and the primary municipal expenditure per capita. Standard errors in parenthesis are clustered at the municipal level. Stars indicate significance levels of $10 \%\left({ }^{*}\right), 5 \%(* *)$, and $1 \%\left({ }^{* * *}\right)$. 
Table 12. Reaction of Municipalities

\begin{tabular}{|c|c|c|c|c|}
\hline & \multicolumn{2}{|c|}{$\ln ($ Primary Expenditures) } & \multicolumn{2}{|c|}{$\ln$ (Business Tax Revenue) } \\
\hline & (1) & $(2)$ & (3) & $(4)$ \\
\hline Treated $\times$ Post Period & $\begin{array}{c}-0.0191 \\
(0.0194)\end{array}$ & $\begin{array}{l}-0.0115 \\
(0.0198)\end{array}$ & $\begin{array}{c}0.0228 \\
(0.2802)\end{array}$ & $\begin{array}{c}0.3866 \\
(0.2822)\end{array}$ \\
\hline Adjusted $\mathrm{R}^{2}$ & 0.238 & 0.270 & 0.041 & 0.081 \\
\hline Municipality FE & $\checkmark$ & $\checkmark$ & $\checkmark$ & $\checkmark$ \\
\hline Nuts $2 \times$ Year FE & $\checkmark$ & $\checkmark$ & $\checkmark$ & $\checkmark$ \\
\hline Controls & & $\checkmark$ & & $\checkmark$ \\
\hline Pop quartiles $\times$ Year FE & & $\checkmark$ & & $\checkmark$ \\
\hline
\end{tabular}

Notes: $\mathrm{N}=2048$. Odd (even) models correspond to column (2) (column (4)) of baseline. The vector of socio-demographic, economic, and political controls includes the age dependency ratio, the share of the workforce with a tertiary degree, the unemployment rate, the consumption of electricity per capita, the percentage of industrial area, a first instance court dummy, a highway dummy, a same political party dummy, a majority dummy, the share of leftist mandates, and the primary municipal expenditure per capita. Standard errors in parenthesis are clustered at the municipal level. Stars indicate significance levels of $10 \%\left({ }^{*}\right), 5 \%\left({ }^{* *}\right)$, and $1 \%\left({ }^{* * *}\right)$. 
Table 13. Firm Survival

\begin{tabular}{|c|c|c|c|c|c|c|}
\hline & \multicolumn{6}{|c|}{ Probability of Surviving } \\
\hline & \multicolumn{2}{|c|}{1 Year } & \multicolumn{2}{|c|}{3 Years } & \multicolumn{2}{|c|}{5 Years } \\
\hline & $(1)$ & $(2)$ & $(3)$ & $(4)$ & $(5)$ & $(6)$ \\
\hline \multirow{3}{*}{ Treated $\times$ Post Period } & \multicolumn{6}{|c|}{ Panel A. Manufacturing } \\
\hline & $0.038^{* * *}$ & $0.046^{* * *}$ & $0.041^{* *}$ & $0.041^{* *}$ & $0.026^{*}$ & $0.030^{*}$ \\
\hline & $(0.010)$ & $(0.010)$ & $(0.017)$ & $(0.016)$ & $(0.015)$ & $(0.017)$ \\
\hline \multirow[t]{2}{*}{ Adjusted $\mathrm{R}^{2}$} & 0.0199 & 0.0200 & 0.0370 & 0.0381 & 0.0418 & 0.0427 \\
\hline & \multicolumn{6}{|c|}{ Panel B. Services } \\
\hline Treated $\times$ Post Period & $\begin{array}{c}0.045^{* * *} \\
(0.008)\end{array}$ & $\begin{array}{c}0.050^{* * *} \\
(0.008)\end{array}$ & $\begin{array}{c}0.041^{* * *} \\
(0.008)\end{array}$ & $\begin{array}{c}0.044^{* * *} \\
(0.009)\end{array}$ & $\begin{array}{c}0.025^{* * *} \\
(0.007)\end{array}$ & $\begin{array}{c}0.026^{* * *} \\
(0.008)\end{array}$ \\
\hline Adjusted $\mathrm{R}^{2}$ & 0.0419 & 0.0422 & 0.0619 & 0.0621 & 0.0571 & 0.0572 \\
\hline Municipality FE & $\checkmark$ & $\checkmark$ & $\checkmark$ & $\checkmark$ & $\checkmark$ & $\checkmark$ \\
\hline Year FE & $\checkmark$ & $\checkmark$ & $\checkmark$ & $\checkmark$ & $\checkmark$ & $\checkmark$ \\
\hline Nuts $2 \times$ Year FE & $\checkmark$ & $\checkmark$ & $\checkmark$ & $\checkmark$ & $\checkmark$ & $\checkmark$ \\
\hline Firm Controls & $\checkmark$ & $\checkmark$ & $\checkmark$ & $\checkmark$ & $\checkmark$ & $\checkmark$ \\
\hline Controls & & $\checkmark$ & & $\checkmark$ & & $\checkmark$ \\
\hline Pop quartiles $\times$ Year FE & & $\checkmark$ & & $\checkmark$ & & $\checkmark$ \\
\hline
\end{tabular}

Notes: $\mathrm{N}=17924$ in Panel A. N=142265 in Panel B. Standard errors in parenthesis are clustered at the municipal level. Firm controls includes $\ln$ (Sales), $\ln$ (Employment), and sector level dummies. The vector of socio-demographic, economic, and political controls includes the age dependency ratio, the share of the workforce with a tertiary degree, the unemployment rate, the consumption of electricity per capita, the percentage of industrial area, a first instance court dummy, a highway dummy, a same political party dummy, a majority dummy, the share of leftist mandates, and the primary municipal expenditure per capita. Stars indicate significance levels of $10 \%(*), 5 \%(* *)$, and $1 \%(* * *)$. 
Table 14. Financing the Activity: Year 0

\begin{tabular}{|c|c|c|c|c|}
\hline & \multicolumn{2}{|c|}{ Short Debt/Assets } & \multicolumn{2}{|c|}{$\ln ($ Short Debt $)$} \\
\hline & $(1)$ & $(2)$ & $(3)$ & $(4)$ \\
\hline \multirow{3}{*}{ Treated $\times$ Post Period } & \multicolumn{4}{|c|}{ Panel A. Manufacturing } \\
\hline & $0.053^{*}$ & $0.073^{* *}$ & $1.603^{* *}$ & $2.043^{* *}$ \\
\hline & $(0.030)$ & $(0.035)$ & $(0.786)$ & $(0.822)$ \\
\hline Adjusted $\mathrm{R}^{2}$ & 0.121 & 0.118 & 0.129 & 0.158 \\
\hline \multirow[t]{2}{*}{$\mathrm{N}$} & 479 & 479 & 479 & 479 \\
\hline & \multicolumn{4}{|c|}{ Panel B. Services } \\
\hline \multirow[t]{2}{*}{ Treated $\times$ Post Period } & 0.007 & 0.008 & 0.201 & 0.253 \\
\hline & $(0.014)$ & $(0.015)$ & $(0.225)$ & $(0.235)$ \\
\hline Adjusted $\mathrm{R}^{2}$ & 0.0144 & 0.0132 & 0.0840 & 0.0849 \\
\hline $\mathrm{N}$ & 4536 & 4536 & 4536 & 4536 \\
\hline Municipality FE & $\checkmark$ & $\checkmark$ & $\checkmark$ & $\checkmark$ \\
\hline Year FE & $\checkmark$ & $\checkmark$ & $\checkmark$ & $\checkmark$ \\
\hline Nuts $2 \times$ Year FE & $\checkmark$ & $\checkmark$ & $\checkmark$ & $\checkmark$ \\
\hline Firm Controls & $\checkmark$ & $\checkmark$ & $\checkmark$ & $\checkmark$ \\
\hline Controls & & $\checkmark$ & & $\checkmark$ \\
\hline Pop quartiles $\times$ Year FE & & $\checkmark$ & & $\checkmark$ \\
\hline
\end{tabular}

Notes: Standard errors in parenthesis are clustered at the municipal level. Firm controls includes $\ln ($ Sales), $\ln$ (Employment), and sector level dummies. The vector of socio-demographic, economic, and political controls includes the age dependency ratio, the share of the workforce with a tertiary degree, the unemployment rate, the consumption of electricity per capita, the percentage of industrial area, a first instance court dummy, a highway dummy, a same political party dummy, a majority dummy, the share of leftist mandates, and the primary municipal expenditure per capita. Stars indicate significance levels of $10 \%(*), 5 \%(* *)$, and $1 \%(* * *)$. 
Table 15. Capital Expenditure and Financing the Activity: Year 5

\begin{tabular}{|c|c|c|c|c|c|c|}
\hline & \multirow{2}{*}{\multicolumn{2}{|c|}{$\frac{\text { Investment }}{\ln \text { (CapExp Buildings) }}$}} & \multicolumn{4}{|c|}{ Financing the Activity } \\
\hline & & & \multicolumn{2}{|c|}{ Debt/Assets } & \multicolumn{2}{|c|}{$\ln ($ Debt $)$} \\
\hline & $(1)$ & $(2)$ & (3) & $(4)$ & $(5)$ & (6) \\
\hline & \multicolumn{6}{|c|}{ Panel A. Manufacturing } \\
\hline Treated $\times$ Post Period & $\begin{array}{c}0.982^{* *} \\
(0.494)\end{array}$ & $\begin{array}{l}1.093^{*} \\
(0.653)\end{array}$ & $\begin{array}{c}10.265 \\
(12.379)\end{array}$ & $\begin{array}{c}8.023 \\
(11.726)\end{array}$ & $\begin{array}{l}1.839^{*} \\
(1.065)\end{array}$ & $\begin{array}{c}2.655^{* *} \\
(1.190)\end{array}$ \\
\hline Adjusted $\mathrm{R}^{2}$ & 0.155 & 0.161 & 0.0019 & 0.0253 & 0.119 & 0.151 \\
\hline $\mathrm{N}$ & \multirow{2}{*}{\multicolumn{6}{|c|}{ Panel B. Services }} \\
\hline & & & & & & \\
\hline Treated $\times$ Post Period & $\begin{array}{l}-0.017 \\
(0.163)\end{array}$ & $\begin{array}{c}0.018 \\
(0.138)\end{array}$ & $\begin{array}{c}1.817 \\
(3.557)\end{array}$ & $\begin{array}{l}1.340 \\
(2.613)\end{array}$ & $\begin{array}{l}-0.448^{*} \\
(0.251)\end{array}$ & $\begin{array}{l}-0.548^{*} \\
(0.292)\end{array}$ \\
\hline Adjusted $\mathrm{R}^{2}$ & 0.0382 & 0.0406 & 0.0012 & 0.0028 & 0.0782 & 0.0793 \\
\hline $\mathrm{N}$ & 4719 & 4719 & 4650 & 4650 & 4720 & 4720 \\
\hline Municipality FE & $\checkmark$ & $\checkmark$ & $\checkmark$ & $\checkmark$ & $\checkmark$ & $\checkmark$ \\
\hline Year FE & $\checkmark$ & $\checkmark$ & $\checkmark$ & $\checkmark$ & $\checkmark$ & $\checkmark$ \\
\hline Nuts $2 \times$ Year FE & $\checkmark$ & $\checkmark$ & $\checkmark$ & $\checkmark$ & $\checkmark$ & $\checkmark$ \\
\hline Firm Controls & $\checkmark$ & $\checkmark$ & $\checkmark$ & $\checkmark$ & $\checkmark$ & $\checkmark$ \\
\hline Controls & & $\checkmark$ & & $\checkmark$ & & $\checkmark$ \\
\hline Pop quartiles $\times$ Year FE & & $\checkmark$ & & $\checkmark$ & & $\checkmark$ \\
\hline
\end{tabular}

Standard errors in parenthesis are clustered at the municipal level. Firm controls includes $\ln$ (Sales), $\ln$ (Employment), and sector level dummies. The vector of socio-demographic, economic, and political controls includes the age dependency ratio, the share of the workforce with a tertiary degree, the unemployment rate, the consumption of electricity per capita, the percentage of industrial area, a first instance court dummy, a highway dummy, a same political party dummy, a majority dummy, the share of leftist mandates, and the primary municipal expenditure per capita. Stars indicate significance levels of $10 \%(*), 5 \%(* *)$, and $1 \%\left(^{* * *}\right)$. 


\section{GEE Papers}

1: Evolução do Comércio Externo Português de Exportação (1995-2004)

João Ferreira do Amaral

2: Nowcasting an Economic Aggregate with Disaggregate Dynamic Factors: An Application to Portuguese GDP Antonio Morgado | Luis Nunes | Susana Salvado

3: Are the Dynamics of Knowledge-Based Industries Any Different?

Ricardo Mamede | Daniel Mota | Manuel Godinho

4: Competitiveness and convergence in Portugal Jorge Braga de Macedo

5: Produtividade, Competitividade e Quotas de Exportação Jorge Santos

6: Export Diversification and Technological Improvement: Recent Trends in the Portuguese Economy Manuel Cabral

7: Election Results and Opportunistic Policies: An Integrated Approach

Toke Aidt | Francisco Veiga | Linda Veiga

8: Behavioural Determinants of Foreign Direct Investment Ricardo Pinheiro-Alves

9: Structural Transformation and the role of Foreign Direct Investment in Portugal: a descriptive analysis for the period 1990-2005

Miguel de Freitas | Ricardo Mamede

10: Productive experience and specialization opportunities for Portugal: an empirical assessment

Miguel de Freitas | Susana Salvado | Luis Nunes | Rui Costa Neves

11: The Portuguese Active Labour Market Policy during the period 1998-2003 - A Compive Conditional DifferenceIn-Differences Application

Alcina Nunes | Paulino Teixeira

12: Fiscal Policy in a Monetary Union: Gains from Changing Institutions

Susana Salvado

13: Coordination and Stabilization Gains of Fiscal Policy in a Monetary Union

Susana Salvado

14: The Relevance of Productive Experience in the Process of Economic Growth: an Empirical Study

Diana Vieira

15: Employment and Exchange rates: the Role of Openness and Technology

Fernando Alexandre | Pedro Bação | João Cerejeira Miguel Portela
16: Aggregate and sector-specific exchange rate indexes for the Portuguese economy

Fernando Alexandre | Pedro Bação | João

Cerejeira | Miguel Portela

17: The Macroeconomic Determinants of Cross Border Mergers and Acquisitions and Greenfield Investments Paula Neto | Antonio Brandao | António Cerqueira

18: Does the location of manufacturing determine service sectors' location choices? Evidence from Portugal Nuno Crespo | Maria Paula Fontoura

19: A hipótese do Investment Development Path: Uma Abordagem por Dados em Painel. Os casos de Portugal e Espanha

Miguel Fonseca | António Mendonça | José Passos

20: Outward FDI Effects on the Portuguese Trade Balance, 1996-2007

Miguel Fonseca | António Mendonça | José Passos

21: Sectoral and regional impacts of the European Carbon Market in Portugal

Margarita Robaina Alves | Miguel Rodriguez | Catarina Roseta-Palma

22: Business Demography Dynamics in Portugal: A NonParametric Survival Analysis

Alcina Nunes | Elsa Sarmento

23: Business Demography Dynamics in Portugal: A Semiparametric Survival Analysis Alcina Nunes | Elsa Sarmento

24: Digging Out the PPP Hypothesis: an Integrated Empirical Coverage

Miguel de Carvalho | Paulo Júlio

25: Regulação de Mercados por Licenciamento Patrícia Cerqueira | Ricardo Pinheiro Alves

26: Which Portuguese Manufacturing Firms Learn by Exporting?

Armando Silva | Óscar Afonso | Ana Paula Africano

27: Building Bridges: Heterogeneous Jurisdictions, Endogenous Spillovers, and the Benefits of Decentralization Paulo Júlio | Susana Peralta

28: Análise comparativa de sobrevivência empresarial: o caso da região Norte de Portugal Elsa Sarmento | Alcina Nunes

29: Business creation in Portugal: Comparison between the World Bank data and Quadros de Pessoal Elsa Sarmento | Alcina Nunes

30: The Ease of Doing Business Index as a tool for Investment location decisions João Zambujal Oliveira | Ricardo Pinheiro Alves 
31: The Politics of Growth: Can Lobbying Raise Growth and Welfare?

Paulo Júlio

32: The choice of transport technology in the presence of exports and FDI

José Pedro Ponte | Armando Garcia Pires

33: Tax Competition in an Expanding European Union Ronald Davies | Johannes Voget

34: The usefulness of State trade missions for the internationalization of firms: an econometric analysis Ana Paula Africano | Aurora Teixeira | André Caiado

35: The role of subsidies for exports: Evidence from Portuguese manufacturing firms Armando Silva

36: Criação de empresas em Portugal e Espanha: análise comparativa com base nos dados do Banco Mundial Elsa Sarmento | Alcina Nunes

37: Economic performance and international trade engagement: the case of Portuguese manufacturing firms

Armando Silva | Oscar Afonso | Ana Paula Africano

38: The importance of Intermediaries organizations in international R\&D cooperation: an empirical multivariate study across Europe

Aurora Teixeira | Margarida Catarino

39: Financial constraints, exports and monetary integration Financial constraints and exports: An analysis of Portuguese firms during the European monetary integration

Filipe Silva | Carlos Carreira

40: FDI and institutional reform in Portugal

Paulo Júlio | Ricardo Pinheiro-Alves | José Tavares

41: Evaluating the forecast quality of GDP components Paulo Júlio | Pedro Esperança | João C. Fonseca

42: Assessing the Endogeneity of OCA conditions in EMU Carlos Vieira | Isabel Vieira

43: Labor Adjustment Dynamics: An Application of System GMM

Pedro Esperança

44: Corporate taxes and the location of FDI in Europe using firm-level data

Tomás Silva | Sergio Lagoa

45: Public Debt Stabilization: Redistributive Delays versus Preemptive Anticipations Paulo Júlio

46: Organizational Characteristics and Performance of Export Promotion Agencies: Portugal and Ireland compared Inês Ferreira | Aurora Teixeira
47: Evaluating the forecast quality of GDP components: An application to G7

Paulo Júlio | Pedro Esperança

48: The influence of Doing Business' institutional variables in Foreign Direct Investment Andreia Olival

49: Regional and Sectoral Foreign Direct Investment in Portugal since Joining the EU: A Dynamic Portrait Irina Melo | Alexandra Lopes

50: Institutions and Firm Formation: an Empirical Analysis of Portuguese Municipalities

Simão Arouca

51: Youth Unemployment in Southern Europe João Leão | Guida Nogueira

52: Financiamento da Economia Portuguesa: um Obstáculo ao Crescimento?

João Leão | Ana Martins | João Gonçalves

53: O Acordo de Parceria Transatlântica entre a UE e os EUA constitui uma ameaça ou uma oportunidade para a Economia Portuguesa?

João Leão | Guida Nogueira

54: Prescription Patterns of Pharmaceuticals Ana Gonçalves

55: Economic Growth and the High Skilled: the Role of Scale Eects and of Barriers to Entry into the High Tech Pedro Gil | Oscar Afonso | Paulo Brito

56: Finanças Públicas Portuguesas Sustentáveis no Estado Novo (1933-1974)?

Ricardo Ferraz

57: What Determines Firm-level Export Capacity? Evidence from Portuguese firms

Ana Gouveia I Ana Luisa Correia

58: The effect of developing countries' competition on regional labour markets in Portugal Tiago Pereira

59: Fiscal Multipliers in the 21st century Pedro Brinca | Hans Holter | Per Krusell| Laurence Malafry

60: Reallocation of Resources between Tradable and NonTradable Sectors in Portugal: Developing a new Identification Strategy for the Tradable Sector Ana Fontoura Gouveia | Filipa Canas

61: Is the ECB unconventional monetary policy effective? Inês Pereira

62: The Determinants of TFP Growth in the Portuguese Manufacturing Sector Daniel Gonçalves | Ana Martins 
63: Practical contribution for the assessment and monitoring of product market competition in the Portuguese Economy - estimation of price cost margins Luis Folque

64: The impact of structural reforms of the judicial system: a survey

Ana Gouveia | Silvia Santos | Corinna Herber

65: The short-term impact of structural reforms on productivity growth: beyond direct effects

Ana Gouveia | Silvia Santos | Inês Gonçalves

66: Assessing the Competitiveness of the Portuguese Footwear Sector

Fábio Batista | José Matos | Miguel Matos

67: The empirics of agglomeration economies: the link with productivity

Ana Gouveia | Silvia Santos | Marli Fernandes

68: Determinants of the Portuguese GDP stagnation during the 2001-2014 period: an empirical investigation Carlos Figueira

69: Short-run effects of product markets' deregulation: a more productive, more efficient and more resilient economy? Ana Gouveia | Silvia Santos | Gustavo Monteiro

70: Portugal: a Paradox in Productivity Ricardo Pinheiro Alves

71: Infrastructure Investment, Labor Productivity, and International Competitiveness: The Case of Portugal Alfredo Pereira | Rui Pereira

72: Boom, Slump, Sudden stops, Recovery, and Policy Options. Portugal and the Euro

Olivier Blanchard | Pedro Portugal

73: Case Study: DBRS Sovereign Rating of Portugal. Analysis of Rating Methodology and Rating Decisions Annika Luisa Hofmann | Miguel Ferreira | João Lampreia

74: For Whom the Bell Tolls: Road Safety Effects of Tolls on Uncongested SCUT Highways in Portugal Alfredo Pereira | Rui Pereira | João Pereira dos Santos

75: Is All Infrastructure Investment Created Equal? The Case of Portugal

Alfredo Pereira | Rui Pereira

76: Why Virtuous Supply-Side Effects and Irrelevant Keynesian Effects are not Foregone Conclusions: What we Learn from an Industry-Level Analysis of Infrastructure Investments in Portugal

Alfredo Pereira | Rui Pereira

77: The Role of Gravity Models in Estimating the Economic Impact of Brexit

Graham Gudgin | Ken Coutts | Neil Gibson | Jordan Buchanan

78: Infrastructure Investment in Portugal and the Traded/NonTraded Industry Mix

Alfredo Pereira | Rui Pereira
79: Goods and Factor Market Integration: A Quantitative Assessment of the EU Enlargement

Lorenzo Caliendo | Fernando Parro | Luca David Opromolla | Alessandro Sforza

80: Understanding productivity dynamics:a task taxonomy approach

Tiago Fonseca | Francisco Lima | Sonia C. Pereira

81: On the Effects of Infrastructure Investments on Industrial $\mathrm{CO} 2$ Emissions in Portugal

Alfredo Pereira | Rui Pereira

82: Assessing Competition With the Panzar-Rosse Model: An empirical analysis of European Union banking industry Suzana Cristina Silva Andrade

83: Health Care Investments and Economic Performance in Portugal: An Industry Level Analysis Alfredo Pereira | Rui Pereira | Pedro G. Rodrigues

84: Is deregulation of product and labour markets promoting employment and productivity? A difference-indifferences approach

Hugo Correia | Ana Fontoura Gouveia

85: Foreign acquisition and internal organization Paulo Bastos | Natália P. Monteiro | Odd Rune Straume

86: Learning, Prices, and Firm Dynamics Paulo Bastos | Daniel A. Dias | Olga A. Timoshenko

87: The Diffusion of Knowledge via Managers' Mobility Giordano Mion | Luca David Opromolla|Alessandro Sforza

88: Empresas Zombie em Portugal - Os sectores não transacionáveis da Construção e dos Serviços Gabriel Osório de Barros | Filipe Bento Caires | Dora Xarepe Pereira

89: Collective bargaining through the magnifying glass: A comparison between the Netherlands and Portugal Alexander Hijzen | Pedro Martins | Jante Parlevliet

90: A Lower VAT Rate on Electricity in Portugal: Towards a Cleaner Environment, Better Economic Performance, and Less Inequality Alfredo Pereira | Rui Manuel Pereira

91: Who Seeks Re-Election: Local Fiscal Restraints and Political Selection

Susana Peralta | João Pereira dos Santos

92: Assessing the Competitiveness of the Metalworking Sector João Marinho | Pedro Carvalho

93: The efficiency of Portuguese Technology Transfer Offices and the importance of university characteristics Aurora Teixeira | André Monteiro

94: Persistence in innovation and innovative behavior in unstable environments Joana Costa | Anabela Botelho | Aurora Teixeira 
95: The effect of entrepreneurial origin on firms' performance - The case of Portuguese academic spinoffs Natália Barbosa | Ana Paula Faria

96: Absorptive Capacity and Firms' Generation of Innovation Revisiting Zahra and George's Model Dina Pereira | João Leitão

97: Innovations in digital government as business facilitators: implications for Portugal João Martins | Linda Veiga

98: Innovation and the economic downturn: Insights from Portuguese firms

Hugo Pinto | Tiago Santos Pereira | Elvira Uyarra

99: European Funds and Firm Dynamics: Estimating Spillovers from Increased Access

João Pereira dos Santos | José Tavares

100: Corporate Leverage and Investment in Portugal Ana Martins | José Henrique Gonçalves | João Mário Ferreira Duque

101: The effects of official and unofficial information on tax compliance

Filomena Garcia | Luca David Opromolla | Andrea Vezzulli | Rafael Marques

102: Competition effect on innovation and productivity - The Portuguese case

Anabela Santos | Michele Cincera | Paulo Neto | Maria Manuel Serrano

103: Measuring the Welfare of Intermediation in Vertical Markets

Javier D. Donna | Pedro Pereira | Tiago Pires | Andre Trindade

104: Of course Collusion Should be Prosecuted. But Maybe... Or (The case for international antitrust agreements) Filomena Garcia | Jose Manuel Paz y Minõ | Gustavo Torrens

105: Product market competition and gender discrimination Dudley Cooke | Ana P. Fernandes | Priscila Ferreira

106: Integration of Small Technology-Based Firms in Aeronautics

Anabela Reis | Joana Mendonça | Ligia Urbina

107: The Effects of Highway Tolls on Private Business Activity Results from a Natural Experiment João Pereira dos Santos | David B. Audretsch | Dirk Dohse

108: Competition and Firm Productivity: Evidence from Portugal

Pedro Carvalho

109: Do Exchange Traded Funds (ETFs) Outperform the Market? Evidence from the Portuguese Stock Index Carlos Manuel Pinheiro | Hugo Hilário Varela
110: Assessing the Competitiveness of the Portuguese Chemical Sector

Ana Rita Marques | Cátia Silva

111: A General Equilibrium Theory of Occupational Choice under Optimistic Beliefs about Entrepreneurial Ability Michele Dell'Era | Luca David Opromolla | Luis SantosPinto

112: O Mercado Segurador em Portugal: O Papel dos Gestores na Constituição de Provisões

Soraia de Sousa Bornett | Carlos Manuel Pinheiro

113: Exploring the implications of di erent loan-to-value macroprudential policy designs

Rita Basto | Sandra Gomes | Diana Lima

114: The Determinants of TFP Growth in the Portuguese Service Sector

Ana Martins | Tiago Domingues | Catarina Branco

115: Agglomeration and Industry Spillover Effects in the Aftermath of a Credit Shock José Jorge | Joana Rocha

116: Entrepreneurial Human Capital and Firm Dynamics Francisco Queiró

117: Global Value Chains and Vertical Specialization: The case of Portuguese Textiles and Shoes exports

Tiago Domingues

118: Firm heterogeneity and exports in Portugal: Identifying export potential Frederico Oliveira Torres

119: Vantagens Comparativas Reveladas e suas determinantes: Uma Aplicação à Economia Portuguesa Guida Nogueira | António Portugal Duarte

120: A Look at the main channels of Potential Impact of Brexit on the Portuguese Economy Guida Nogueira | Paulo Inácio

121: How internationalization and competitiveness contribute to get public support to innovation? The Portuguese case

Anabela Santos, Michele Cincera, Paulo Neto and Maria Manuel Serrano

122: Grande Guerra e Guerra Colonial: Quanto Custaram aos Cofres Portugueses?

Ricardo Ferraz

123: Financing a Renewable Energy Feed-in Tariff with a Tax on Carbon Dioxide Emissions: A Dynamic Multi-Sector General Equilibrium Analysis for Portugal Rui M. Pereira | Alfredo M. Pereira

124: Brown Sugar, how come you taste so good? The impact of a soda tax on prices and consumption Judite Gonçalves | João Pereira dos Santos

125: ARFIMA Reference Forecasts for Worldwide $\mathrm{CO} 2$ Emissions and the National Dimension of the Policy Efforts to Meet IPCC Targets José Beirute | Alfredo M. Pereira 
126: Reference Forecasts for CO2 Emissions from Fossil-Fuel Combustion and Cement Production in Portugal José M. Belbute | Alfredo M. Pereira

127: Regulated Early Closures of Coal-Fired Power Plants and Tougher Energy Taxation on Electricity Production: Synergy or Rivalry?

Alfredo Marvão Pereira | Rui Manuel Pereira

128: Picking Our Environmental Battles: Removal of Harmful Subsidies or Carbon Taxation?

Alfredo Marvão Pereira | Rui Marvão Pereira

129: Financing Future Feed-in Tariffs from Currently Installed RES-E Generating Capacity

Alfredo Marvão Pereira | Rui Marvão Pereira

130: Foreign Direct Investment, Income Inequality and Poverty in Portugal, 1973-2014: What does cointegration analysis tell us?

Aurora Teixeira | Ana Sofia Loureiro

131: On the Spillover Effects of CO2 Taxation on the Emissions of other Air Pollutants

Alfredo Marvão Pereira | Rui Marvão Pereira

132: On the Macroeconomic and Distributional Effects of the Regulated Closure of Coal-Operated Power Plants Alfredo Marvão Pereira | Rui Manuel Pereira

133: The China Shock and Employment in Portuguese Firms Lee Branstetter | Brian Kovak | Jacqueline Mauro | Ana Venâncio

134: Energy Taxation Reform with an Environmental Focus Alfredo Marvão Pereira | Rui Manuel Pereira

135: ARFIMA Reference Forecasts for Worldwide $\mathrm{CO} 2$ Emissions and the Need for Large and Frontloaded Decarbonization Policies José M. Belbute | Alfredo M. Pereira

136: Exporter Firms Behaviour, Evidence From Portuguese Firms Using Microdata Luís Pedro Manso Machado

137: Collateral Value and Entrepreneurship: Evidence from a Property Tax Reform

Miguel Ferreira | João Pereira dos Santos | Ana Venâncio 


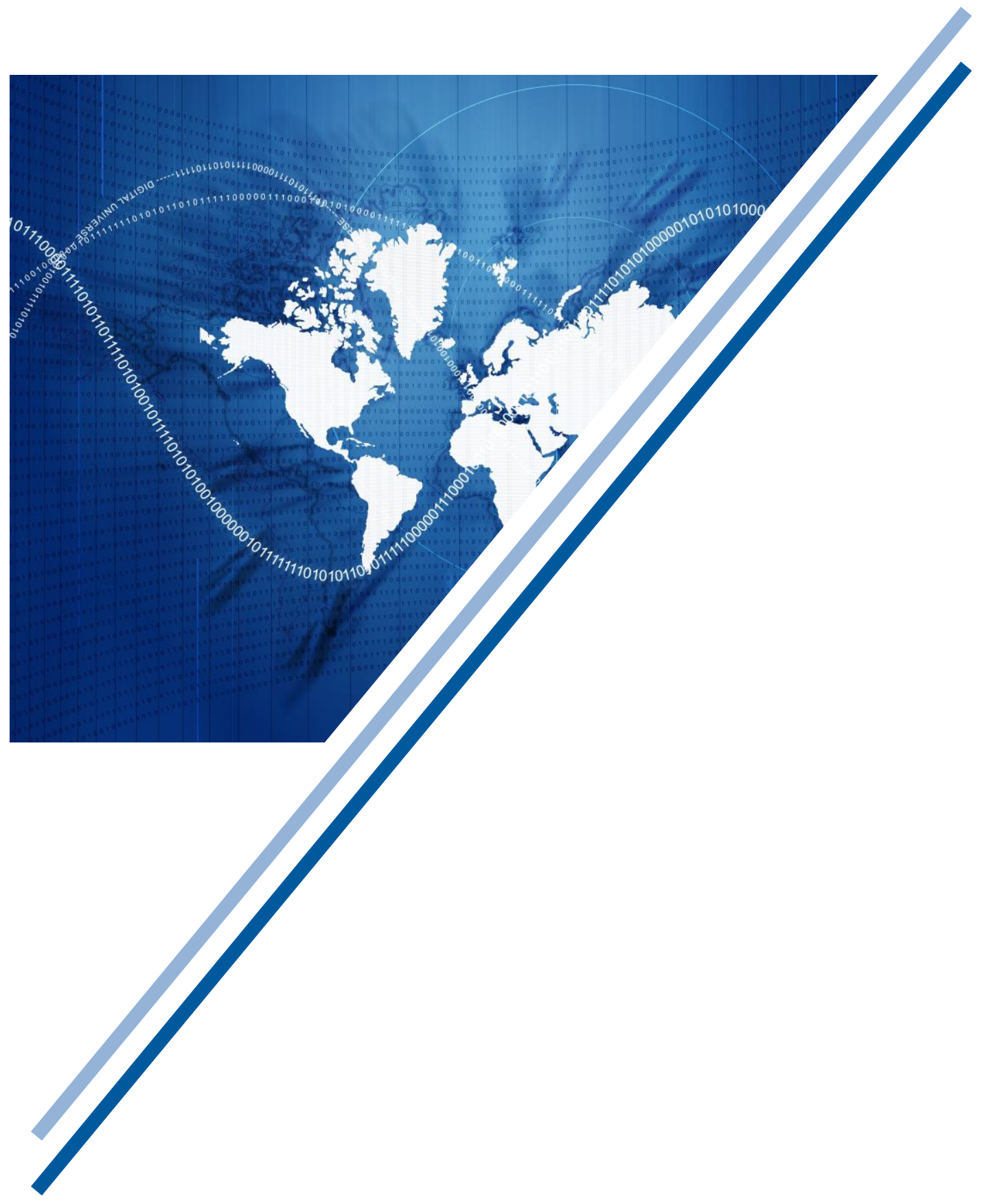

